\title{
Integrated strategy for sustainable cattle fever tick eradication in USA is required to mitigate the impact of global change
}

\author{
Adalberto A. Pérez de León ${ }^{1}{ }^{\dagger}$, Pete D. Teel ${ }^{2+}$, Allan N. Auclair ${ }^{3}$, Matthew T. Messenger $^{4}$, Felix D. Guerrero ${ }^{1}$, \\ Greta Schuster ${ }^{5}$ and Robert J. Miller ${ }^{6}$ \\ ${ }^{1}$ Knipling-Bushland U.S. Livestock Insects Research Laboratory, United States Department of Agriculture - Agricultural Research Service, Kerrville, TX, USA \\ ${ }^{2}$ Department of Entomology, Texas A\&M University, College Station, TX, USA \\ ${ }^{3}$ Risk Analysis Systems, United States Department of Agriculture - Animal and Plant Health Inspection Service, Riverdale, MD, USA \\ ${ }^{4}$ Cattle Fever Tick Eradication Program, United States Department of Agriculture - Animal and Plant Health Inspection Service, Veterinary Services, Riverdale, MD, \\ USA \\ ${ }^{5}$ Department of Agriculture, Agribusiness and Environmental Sciences, Texas A\&M University-Kingsville, Kingsville, TX, USA \\ ${ }^{6}$ Cattle Fever Tick Research Laboratory, United States Department of Agriculture - Agricultural Research Service, Edinburg, TX, USA
}

\section{Edited by:}

Rubén Bueno-Marí, University of Valencia, Spain

Reviewed by:

Ali Torkamani, University of California at San Diego, USA

Nordin Zeidner, Centers for Disease

Control and Prevention, USA

Katherine Kocan, Oklahoma State

University, USA

*Correspondence:

Adalberto A. Pérez de León,

Knipling-Bushland U.S. Livestock

Insects Research Laboratory, United

States Department of Agriculture -

Agricultural Research Service, 2700

Fredericksburg Drive, Kerrville, TX

78028, USA.

e-mail:beto.perezdeleon@

ars.usda.gov

${ }^{\dagger}$ Adalberto A. Pérez de León and Pete $D$. Teel have contributed equally to this work.
The ticks Rhipicephalus (Boophilus) annulatus and R. (B.) microplus, commonly known as cattle and southern cattle tick, respectively, impede the development and sustainability of livestock industries throughout tropical and other world regions. They affect animal productivity and wellbeing directly through their obligate blood-feeding habit and indirectly by serving as vectors of the infectious agents causing bovine babesiosis and anaplasmosis. The monumental scientific discovery of certain arthropod species as vectors of infectious agents is associated with the history of research on bovine babesiosis and $R$. annulatus. Together, $R$. microplus and $R$. annulatus are referred to as cattle fever ticks (CFT). Bovine babesiosis became a regulated foreign animal disease in the United States of America (U.S.) through efforts of the Cattle Fever Tick Eradication Program (CFTEP) established in 1906. The U.S. was declared free of CFT in 1943, with the exception of a permanent quarantine zone in south Texas along the border with Mexico. This achievement contributed greatly to the development and productivity of animal agriculture in the U.S. The permanent quarantine zone buffers CFT incursions from Mexico where both ticks and babesiosis are endemic. Until recently, the elimination of CFT outbreaks relied solely on the use of coumaphos, an organophosphate acaricide, in dipping vats or as a spray to treat livestock, or the vacation of pastures. However, ecological, societal, and economical changes are shifting the paradigm of systematically treating livestock to eradicate CFT. Keeping the U.S. CFT-free is a critical animal health issue affecting the economic stability of livestock and wildlife enterprises. Here, we describe vulnerabilities associated with global change forces challenging the CFTEP. The concept of integrated CFT eradication is discussed in reference to global change.

Keywords: cattle, tick, babesiosis, integrated eradication, global change, climate, modeling, sustainability

\section{INTRODUCTION}

Global change makes human and animal populations vulnerable to emerging and re-emerging tick-borne diseases. Environmental and climatic changes ascribed to human activity are collectively referred to as global change (Sutherst, 2001; Camill, 2010). The accelerated rate of global change alters the epidemiology of tickborne diseases. Tick-borne diseases are complex systems subject to shifts in ecological processes influencing tick biology and consequently the epidemiology of pathogens transmitted by ticks (Randolph, 2010; Reisen, 2010; Tabachnick, 2010; Olson and Patz, 2011). This review explores the ramifications of global change on the Cattle Fever Tick Eradication Program (CFTEP) of the United States of America (U.S.) and how these challenges threaten the ability to keep the national cattle herd free of bovine babesiosis by suppressing the invasive cattle fever tick (CFT) vectors, Rhipicephalus (Boophilus) annulatus and $R$. (B.) microplus. The reader is referred to the review by Aubry and Geale (2011) for details on bovine anaplasmosis, which is another economically important infectious disease of cattle caused by Anaplasma marginale and transmitted by CFT.

Research on bovine babesiosis and CFT involves a notable discovery in the history of medical science. Elegant studies by Smith and Kilbourne (1893) revealed that the apicomplexan protozoon Babesia bigemina transmitted by $R$. annulatus caused bovine babesiosis in susceptible cattle. We now know that $R$. microplus also transmits $B$. bovis, which causes a more virulent form of bovine babesiosis. Smith and Kilborne's monumental work was soon followed by others reporting the role of various 
blood-feeding arthropod species, such as lice and mosquitoes, transmitting pathogens to humans and animals causing severe maladies like malaria, yellow fever, typhus, and dengue (Schultz, 2008). Cooper Curtice also made invaluable contributions to the history of CFT and bovine babesiosis research. His detailed investigations describing the life history of CFT laid the foundation for the CFTEP (Logue, 1995). The interaction between Smith, a physician, and Kilborne, a veterinarian, is a fine example of what we now term the One Health (Bulloch, 1935). The One Health concept defines the collaborative effort of multiple disciplines to attain optimal health for people, animals, and our environment (Welburn, 2011). Such approach identified knowledge gaps in human and bovine babesioses and the benefits of its application to the CFTEP are reflected in progress to translate research into tools that can be integrated to minimize the impact of CFT outbreaks on U.S. agriculture, which are described here (Pérez de León et al., 2010).

Bovine babesiosis is a devastating tick-borne disease of cattle that was eradicated from the U.S. by eliminating CFT populations. This significant event in the history of disease eradication campaigns was accomplished through the efforts of the CFTEP managed by state and federal agencies in collaboration with livestock producers from 1907 until 1943. A permanent quarantine zone established in Texas extending over $800 \mathrm{~km}$ from Del Rio to Brownsville and delimited in the south by the Rio Grande, known in Mexico as Río Bravo, is managed by the U.S. Department of Agriculture-Animal Health Inspection Service (USDA-APHIS) and the Texas Animal Health Commission (TAHC) to buffer tick and stray animal incursions from Mexico where CFT and bovine babesiosis are endemic (Figure 1A).

Keeping the U.S. cattle herd free of bovine babesiosis and CFT is an important animal health issue. Previous estimates converted to today's currency rate indicate that the livestock industry realizes annual savings of at least 3 billion dollars since the U.S. was declared free of bovine babesiosis and CFT (Graham and Hourrigan, 1977). The dynamics of global change have increased the risk for re-emergence of CFT and bovine babesiosis in the U.S. (Bram et al., 2002; Guerrero et al., 2007; George et al., 2008). This risk poses significant challenges to future efforts by the CFTEP. Portions of the U.S. still provide suitable habitat for CFT (EstradaPeña et al., 2005), which correspond with the CFT historical range before the CFTEP was initiated particularly in the 13 states comprising the Southern Region (Figure 1A). Cattle and calves rank among the top five agricultural commodities in nine of the 13 Southern Region states with cash receipts ranging from 5.3\% (Florida) to $46 \%$ (Oklahoma) of all agricultural commodities. The cow-calf inventory of the 13 Southern Region states is more than $42 \%$ of the entire U.S. beef cattle inventory (McBride and Mathews, 2011). Approximately $1 / 3$ of all U.S. fed-cattle originate from Southern Region ranches operated by over 400,000 producers representing nearly $49 \%$ of all U.S. cow-calf producers. The economic stability of the cattle industry is vital to the nation.

Global change involves disruptive processes that augment instability in ecosystems, and the services they provide, that are or can be inhabited by ticks (Hanson et al., 2008). These processes add uncertainty to future outcomes of current policies to manage ticks and tick-borne diseases. The disruptive processes driving

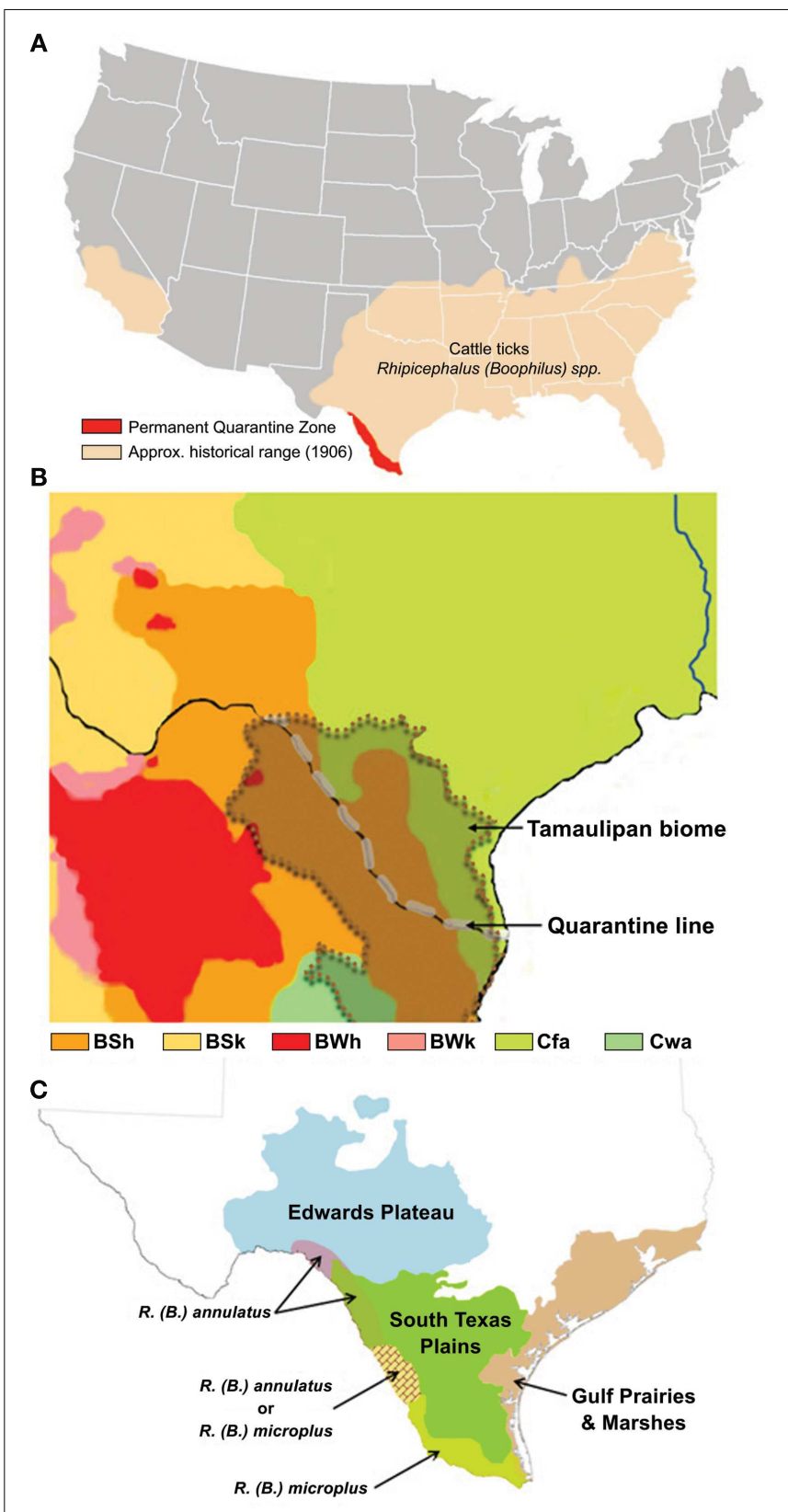

FIGURE 1 | (A,C) The U.S. distribution of cattle ticks in 1906 depicts the zone of risk for tick re-establishment and the permanent quarantine zone along the Texas-Mexico international boundary and quarantine line (A), as adapted from Graham and Hourrigan (1977); the Tamaulipan biome of the Texas-Mexico border area (Scifres, 1985), indicated by the overlay with dotted boundary $(\mathbf{B})$, is the major ecoregion comprising the quarantine zone that consists of four Koppen-Geiger climate classifications, as adapted from Peel et al., 2007, where the majority of the biome is of an arid-steppe (BSh) classification linked with the Temperate (Cfa) classification that extends throughout the historical range of cattle fever ticks, whereas in Mexico the biome includes small areas with climate generally classified as Arid desert (BWh) or Temperate (Cwa); the distribution of ecoregions, as adapted from Correll and Johnston (1970), reflects the diversity of ecological and environmental resources $(\mathbf{C})$, and is integrated with an overlay showing the quarantine zone distribution of recorded incursions of $R$. annulatus and R. microplus, as adapted from Lohmeyer et al. (2011). 
emergence and re-emergence of tick-borne diseases affecting livestock linked to global change include the alteration of ecosystems and agroecosystems, incursion of natural habitats by humans and animals, shifts in land-use, movement of people and animals, climate change, selection of acaricide-resistant tick populations, increased international trade and travel, civil unrest, expansion of tick and pathogen host range, and governmental or management failure (Pegram et al., 2000; Harrus and Baneth, 2005; George, 2008; De Meeûs et al., 2010; Brouqui, 2011; Perry et al., 2011; Food and Agriculture Organization of the United Nations (FAO), 2011). The deterioration of public safety on the Mexican side of the border in south Texas related to illegal drug activity has complicated efforts by the CFTEP (Aguilar, 2011). Such effects are compounded by the zoonotic nature of some tick-borne diseases and the vulnerability of public health and central veterinary authorities trying to deal with the unexpected consequences of global change (Hoberg et al., 2008; Jones et al., 2008; Black and Nunn, 2009; Munderloh and Kurtti, 2011). Tick species other than $R$. microplus and $R$. annulatus serve as vectors of zoonotic babesioses (Vannier et al., 2008).

Our ability to assess immediate and future impacts of global change on animal pests and diseases needs to be enhanced. Bovine babesiosis and CFT are among the diseases and pests requiring attention (Cumming and Van Vuuren, 2006; Food and Agriculture Organization of the United Nations (FAO), 2008). Agriintelligence and foresight are two provocative methodologies that have been applied to better understand and proactively recognize threats and risks to national security associated with agriculture to ensure today's decisions anticipate and incorporate adaptive strategies related to an uncertain future (Munroe, 2007; Munroe and Willis, 2007; Willis, 2007; Suk et al., 2008; Pretty et al., 2010). The incorporation of inputs from diverse disciplines and organizations with broad mandates is a goal of agri-intelligence, which enables analysis through networks aimed at synergizing efforts to deliver a value-added output decision makers can use to make more informed policy development and superior operational outcomes (Munroe, 2007). Foresight is a process that looks at the time horizon to facilitate forward preparedness efforts through critical thinking focused on exploring scenarios including those that may appear unlikely today (Smith, 2007). Forecasting approaches, including modeling, are advocated as a means to facilitate anticipation and enhance prevention, preparedness, and the management of disease outbreaks (Baylis and Githeko, 2006; Garner et al., 2007; Munroe and Willis, 2007; Estrada-Peña, 2008; Woolhouse, 2011).

The principles of agri-intelligence and foresight are applied here to dissect the forces of global change and discern the interconnectedness between environmental and anthropogenic factors driving the temporal and spatial variation of CFT outbreaks in south Texas. This exercise was framed by the historical record of CFT outbreaks in the U.S. since 1959 (Figure 2), and it provides further assessment of CFT and bovine babesiosis research needs identified through a process that applied the One Health concept (Pérez de León et al., 2010). The historical situation with CFT is outlined to reveal critical challenges the CFTEP is facing. Such aspects unify the past, present, and future. This perspective provided a lens to recognize and appreciate the complexity of, and the relationships between issues the CFTEP must contend with to contain CFT within the permanent quarantine zone. The correlates and trends with global change described below formed the basis to suggest a framework for the integration of CFT eradication strategies that could be used to enhance the ability of regulatory agencies in the U.S. to anticipate, prepare for, mitigate, and prevent the burden of CFT outbreaks thereby contributing to the benefits society derives from having a sustainable livestock production system (Figure 3). Sustainability in this context means continued productivity into the indefinite future through the use of sound scientific evidence to inform decision making and guide policy makers involved with the CFTEP while maximizing agroeconomic opportunities for livestock producers (National Research Council of the National Academies, 2010; Simmons, 2011; Walker, 2011).

\section{ARRIVAL AND SPREAD OF CATTLE FEVER TICKS IN THE U.S.}

The CFT are not native to the Americas. The origin of $R$. annulatus includes the arid and temperate climates of southern Russia, the Near- and Middle-East, and the Mediterranean basin whereas the origin of $R$. microplus is the tropical climates of the Indian subcontinent (George, 1990; Estrada-Peña et al., 2006). Evidence indicates that Spanish colonialists served as the pathway that brought livestock infested with CFT and infected with bovine babesiosis to Mexico and Cuba during the 1500s (García-García et al., 1999). The introduction and spread of CFT into what is now the U.S. followed the pattern of North American settlement and commerce. It is suspected that by the end of the eighteenth century bovine babesiosis and $R$. annulatus had emerged in the U.S. because in 1795 North Carolina prohibited driving cattle into the state from South Carolina or Georgia between 1 April and 1 November of each year due to an undetermined disease of livestock (George, 1989). By the late 1800's, CFT were distributed throughout the southern states and southern California (Figure 1A). Bishopp (1913) first reported cattle infestations with $R$. microplus after collecting the ticks in 1912 from animals in Key West, Florida; he speculated that this CFT arrived from the Caribbean islands through commerce. The ticks and bovine babesiosis, known earlier as Texas, Mexican, Spanish, or splenetic fever, were significant economic impediments to cattle industry development throughout the Southern U.S. (Malone, 1989; Strom, 2009). High mortality rates in non-immune animals brought into the Southern states rendered efforts to develop cattle production through improved breeding and management useless. Before eradication, CFT infestation alone reduced the weight of a $500 \mathrm{~kg}$ steer by $100 \mathrm{~kg}$ in a year and reduced milk production of dairy cattle by 25\% (Agricultural Research Service, 1968).

The common name "cattle tick" was derived in part from the devastating economic impact these parasites had on cattle, and in part from their adaptation to this domestic host (Hoogstraal and Aeschlimann, 1982). However, new parasitic relationships have evolved as CFT invaded various parts of the world. Non-bovine hosts of these parasites include buffalo, ox, horse, mule, donkey, sheep, goat, dog, swine, antelope, and several species of deer (Cooley, 1946; Barré et al., 2001; Ghosh et al., 2007; Cançado et al., 2009; Pound et al., 2010). Ticks spend most of their life in the environment off the host in the egg and larval stages (Figure 4), a period that may last 6-9 months depending on microclimates produced by vegetation communities and rainfall (Newell and Daugherty, 


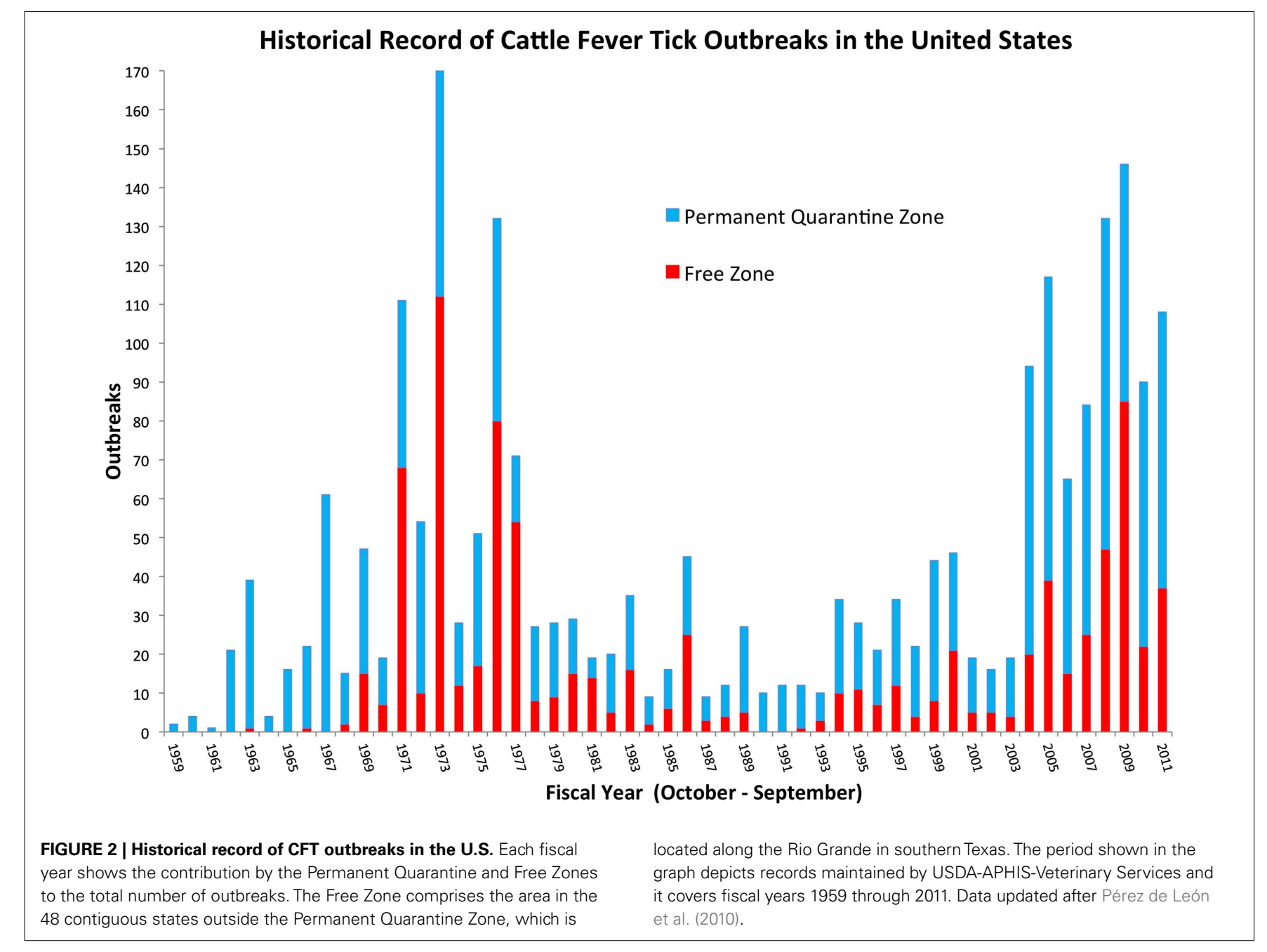

1906; Cotton and Voorhees, 1911; Graybill, 1911). Larvae quest on vegetation for, and eventually attach to a passing host, seek a predilection site to attach and then blood feed. The parasitic portion of their life is completed on the same animal. Therefore, CFT have a one-host life cycle (Figure 4). Blood-fed larvae molt into nymphs and the feeding and molting process is repeated to produce male and female adult CFT. Adults mate and gravid, blood-engorged females detach, drop, and oviposit approximately 3,500 eggs in suitable microclimates at the soil-vegetation interface before dying (Davey et al., 1994). The parasitic phase can be completed over 3-4 weeks providing a substantial period for tick dispersal by foraging animals or human transport of infested animals (Walker et al., 2003). Between three and six generations are produced per year depending on tick species and climatic variables of rainfall and temperature (Mount et al., 1991). In wet-dry season climates, populations generally tend to increase during rainy periods and decline during dry periods (McCulloch and Lewis, 1968; Rawlins, 1979; Daynes and Gutierrez, 1980; Cardozo et al., 1984). Additional information on CFT can be accessed through the TickApp ${ }^{1}$ developed to provide educational information on

\footnotetext{
${ }^{1}$ http://tickapp.tamu.edu
}

tick biology, ecology, associated diseases, prevention, protection, control, and management.

\section{HISTORICAL OVERVIEW OF ERADICATION EFFORTS}

Early workers observed that separation of CFT from cattle effectively prevented transmission of babesiosis pathogens, and eventually reduced or eliminated tick populations (Curtis and Francis, 1892; Newell and Daugherty, 1906). Tick elimination tactics included cultural practices and evolved with the development of the plunge dip vat to treat cattle with acaricides (Francis, 1894; Graham and Hourrigan, 1977). Regulations for CFT eradication used surveillance to define the spatial boundaries of infestations and quarantine of cattle and premises to implement treatments. Two strategies were employed for tick elimination. A "pasture vacation" strategy first removed ticks from infested cattle by acaricide dipping allowing removal of animals to alternate noninfested premises, then leaving the infested premises vacated for 6-9 months for tick larvae to perish without a host. A "systematic dipping" strategy treated $100 \%$ of cattle by dipping at 7-14 day intervals for the 6-9 month period. Acaricide concentrations set to kill 99\% of the ticks and effective dip vat management stopped cattle tick development. These procedures required knowing the exact 


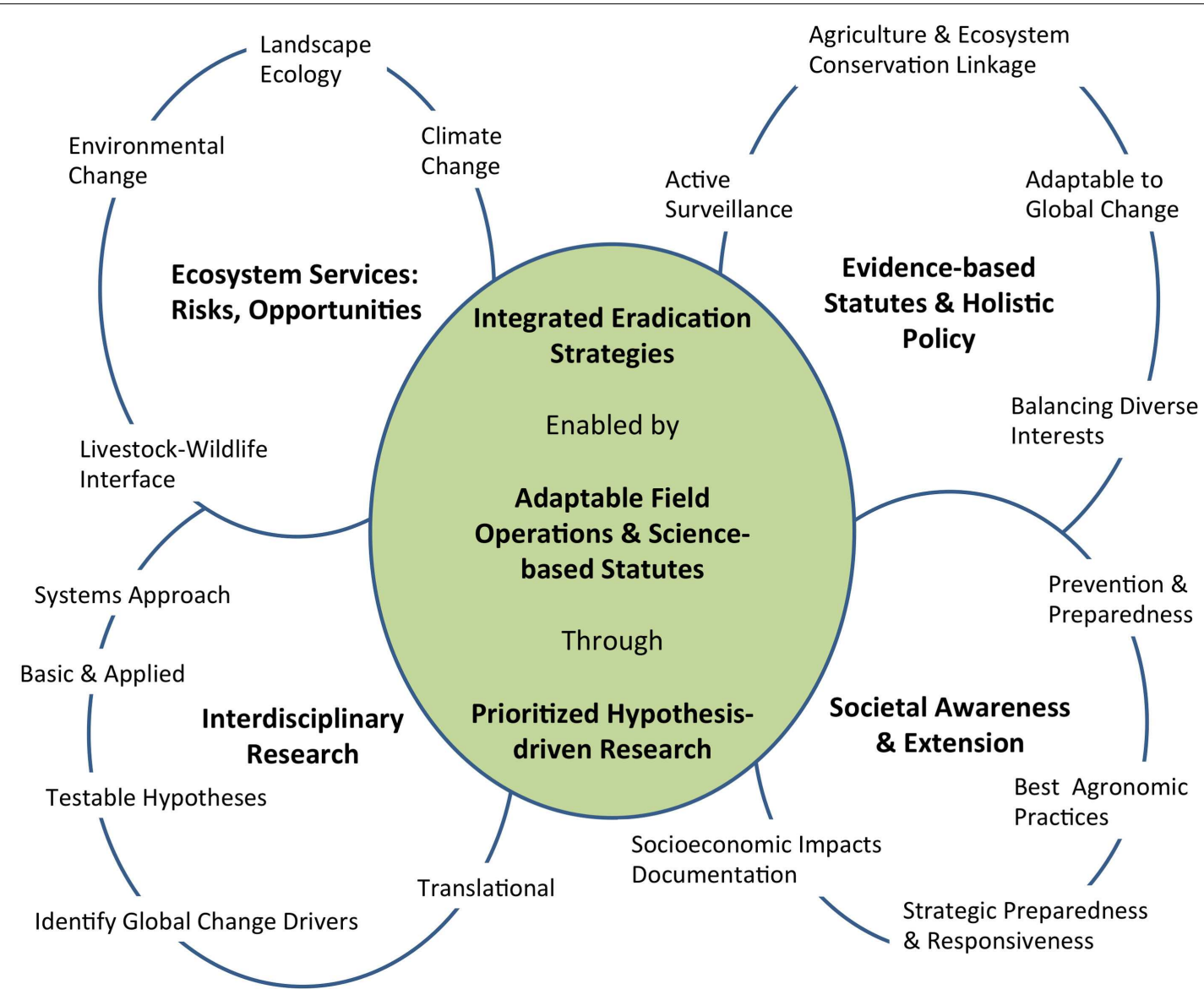

FIGURE 3 | Suggested framework toward integrated cattle fever tick eradication strategies depicting interconnectedness of critical elements for sustainability of bovine babesiosis-free status in the U.S.

cattle inventory at every dipping session and assuring all animals were confined inside fenced premises. Variations on systematic dipping included double fencing, cross fencing, overstocking, and rotations to improve pasture coverage and increase tick-host contact, in effect "sponging" ticks from the premises (Gray et al., 1979). The CFTEP was declared successful in 1943, and the last outbreak of bovine babesiosis in the U.S. occurred in 1949 (Malone, 1989).

Surveillance and detection were critical to identify and contain CFT incursions as well as to assess success of operational tactics. Probabilities of detecting infested animals or premises is the product of many interacting abiotic and biotic factors influencing spatial and temporal distributions of CFT (Palmer et al., 1976; Teel et al., 1997, 2003). When the resident population is low or widely dispersed due to weather conditions, early stage of establishment, or other factors, the probability of detection is low. Continuous active surveillance by well trained personnel and improvements in detection sampling methods and technologies are essential.

\section{IMPACTS OF GLOBAL CHANGE ON OPERATIONS OF THE CATTLE FEVER TICK ERADICATION PROGRAM}

Two spatial and climatic characterizations are relevant to the discussion and interpretation of CFTEP challenges centered in the Tamaulipan scrubland biome, defined as a region whose climate produces similar climax associations of flora and fauna. The Köppen-Geiger climate classification system has recently been updated (Rubel and Kottek, 2010) and provides a common global system for interpretation. A nomenclature for ecological regions, denoted "ecoregions," was developed in the U.S. to identify similarities in type, quality, and quantity of environmental resources as a spatial framework for ecosystem research, assessment, and management (Bryce et al., 1999). This system incorporates variation in biotic and abiotic patterns and composition including geology, physiography, vegetation, climate, soils, land-use, wildlife, and hydrology. Ecoregion names for Texas as defined by Correll and Johnston (1970) will be used in this discussion. We recognize that climate classification continues to be refined through more robust algorithms and this has implications on our understanding of the ways global change shapes the landscape epidemiology of CFT (Rubel and Kottek, 2010; Cannon, 2012). Major aspects related to global change impacting CFTEP operations in the permanent quarantine zone involve shifts in regional ecology, including wildlife fauna as alternative hosts for CFT. Potential future risks include: climate change, human population impacts on land-use and fractionation, acaricide resistance, and infection of wildlife with strains of $B$. bovis and B. bigemina pathogenic to cattle. 


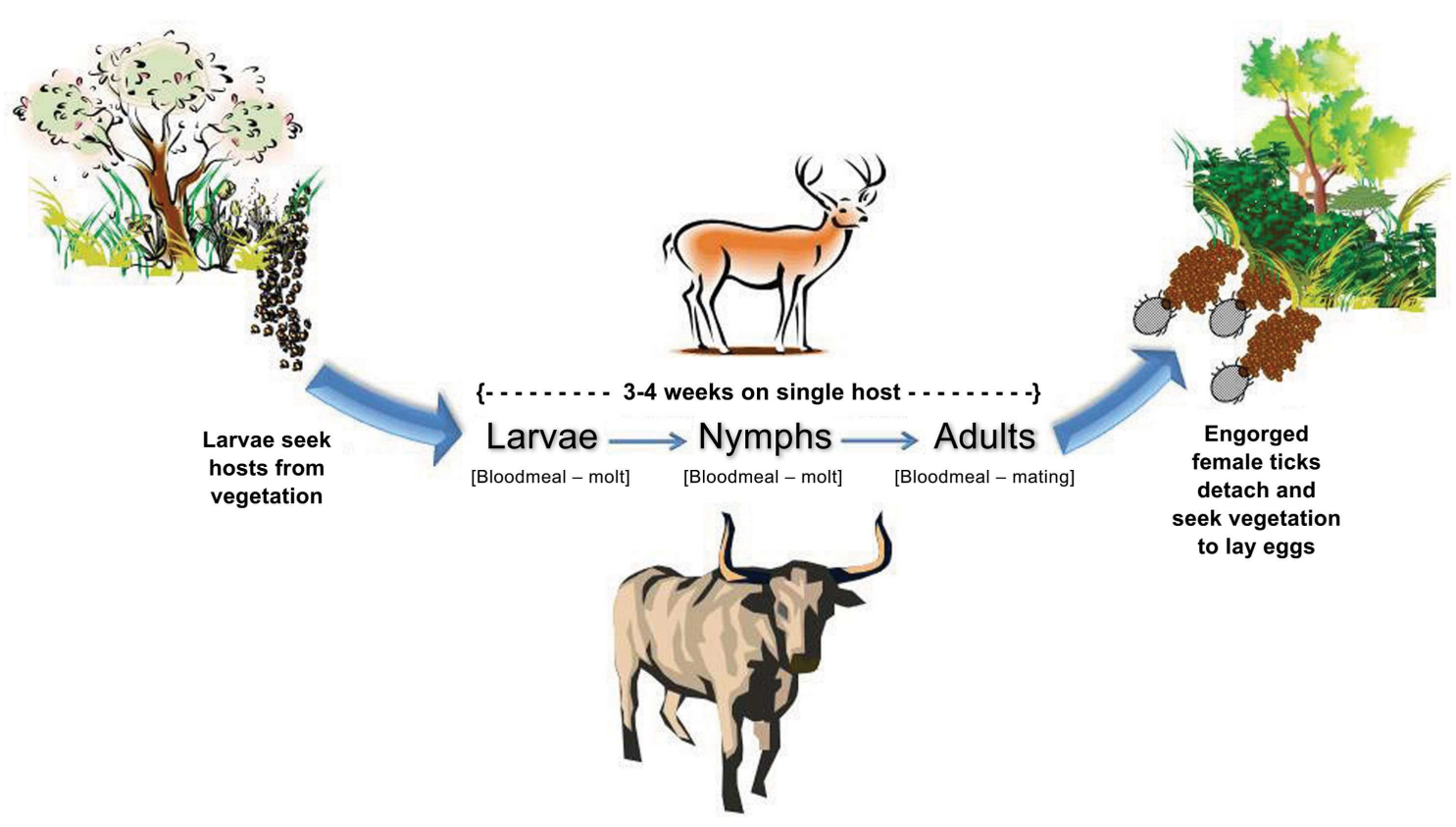

\section{Typical one-host tick life cycle}

FIGURE 4 | One-host life cycle evolved by cattle fever ticks that comprises an on-host phase where larvae and nymphs sequentially blood feed and molt, and adults feed and mate, and an off-host phase in which mated engorged females drop from the host, oviposit, and die. Larvae hatching from the eggs initiate the next generation. In the absence of hosts, the off-host phase may constitute $87-93 \%$ of the life cycle's duration. Used by permission (Teel et al., 2011; http://tickapp.tamu.edu)

\section{SHIFTS IN REGIONAL ECOLOGICAL CHARACTERISTICS}

The Rio Grande marks the U.S.-Mexico boundary in south Texas and this river flows according to rainfall and reservoir containment as it makes its way toward the Gulf of Mexico. With adequate flow, it provides a physical barrier to slow livestock and wildlife movement between countries, while during drought low-water levels permit increased animal and human movement. The river and CFT quarantine zone cross the Tamaulipan scrub biome (Figure 1B). Based upon the updated Köppen-Geiger climate classification (Rubel and Kottek, 2010), the biome climate includes four categories (Figure 1B). The majority of the biome is classified as an arid-steppe (BSh), which changes to a temperate classification (Cfa) in Texas that extends throughout the historical range of CFT in the southern U.S. (Figure 1A), whereas in Mexico it includes small areas with climate generally classified as arid desert (BWh), or temperate (Cwa). The region is comprised of four ecoregions including Gulf Prairies and Marshes, South Texas Plains (also known as Rio Grande Plains), Edwards Plateau (north east of the river and quarantine line), and the Tamaulipan brushlands (south west of the river) (Figure 1C; Correll and Johnston, 1970). Elevation ranges from sea-level to 1000 feet near the most inland locations. Annual rainfall may be $30-50$ inches along the Gulf Coast, but declines to 14-16 inches in the inland reaches of the South Texas Plains-Edwards Plateau. Along the Gulf Coast summers are long, hot and humid (subtropical; Archer et al., 1988) and winters are very mild (>300 frost free days), while progressively more inland locations have hotter, drier summers, and winters subject to more freezing temperatures (Correll and Johnston, 1970). The region is subject to the vagaries of tropical storms from the Caribbean and Gulf of Mexico, as well as periodic and sometimes extended periods of drought. An overlay showing the distribution of CFT species intercepted along the quarantine line reflects the distribution of $R$. microplus in the higher rainfall and more humid areas of the Gulf Prairies and Marshes and South Texas Plains, and the distribution of R. annulatus in the drier inland reaches of the South Texas Plains-Edwards Plateau (Figure 1C; adapted from Lohmeyer et al., 2011). Both species have been intercepted in the narrow area near the middle of the quarantine line. Retrospective climate evaluations found suitable habitat for R. microplus along Gulf and Atlantic coastal states that included a narrow area at the southern end of Texas (EstradaPeña et al., 2005). The derived variables of vapor pressure deficit, evaporation, and total rainfall were the principal determinants explaining variation among the 5-year periods of high suitability. Though no climate or habitat suitability studies have been conducted for R. annulatus, it is expected that this species could re-establish throughout its original range. A recent risk assessment of hypothetical CFT outbreaks in the temperate zone (Cfa; Figure 1B), east of the South Texas Plains, concluded that significant additional infrastructure and personnel would be needed to meet operational demands, and treatment costs and production losses to producers would likely exceed the economic viability of their operations under current tick elimination options (Anderson et al., 2010). 
Descriptions of early landscapes on what is today the Tamaulipan scrubland were of vast grasslands with woody plants limited to sites such as water ways and drainages (Scifres, 1980, 1985). Natural fires, cyclical wet and dry periods, and infrequent grazing by migratory herbivores (e.g., bison, antelope, and deer) minimized overgrazing, and all contributed to the natural management shaping this grassland ecology. Eventual settlement of the area brought about cessation of natural fire and fencing with more intense and long-term grazing by confined herbivores (e.g., cattle, horses, sheep, goats), the combination of which permitted woody plants to expand from their refuges and invade the expanse (Archer et al., 1988). Many areas of South Texas and Northern Mexico eventually gained a continuous cover of brush mottes comprised of large central primary species, such as honey mesquite, Prosopis glandulosa, and as many as 15 secondary species in the community. The anthropogenic alteration of the grassland resulted in brush invasion and the transformation to scrubland. Brush encroachments decreased forage production, the primary resource for rangeland cattle (Scifres, 1980), while concurrently providing more favorable habitat for tick survival (Teel, 1991). Consequently, tactics to control brush were developed into integrated brush management strategies to optimize forage production on fertile sites (Scifres and Hamilton, 1985), and these strategies would ultimately include management for wildlife species as well as cattle (Inglis, 1985). Another pathway for the impact of global change is the facilitative ecological interaction between stands of the non-native giant reed (Arundo donax) and CFT. The giant reed is an invasive weed that consumes economically significant amounts of water in Mexico and the U.S. Giant reed stands along the Rio Grande were shown to provide abiotic and biotic conditions that are favorable for CFT survival (Racelis et al., 2012). Cooperation between the U.S. and Mexico resulted in a control program to control the giant reed using biocontrol agents (Goolsby et al., 2011), which is likely to alleviate complications this invasive weed presents to the CFTEP.

Efforts to improve rangeland forage production also led to the introduction of drought tolerant buffelgrass, Cenchrus ciliaris, from Africa. Rangeland vegetation communities including brush mottes that provide canopy and grasses and forbes of interstitial zones influence the microclimate at the soil-vegetation interface. Spatial distribution of habitats with optimal microclimates interacts with host-landscape behavior to disperse and sustain CFT populations. Management practices for brush control, forage production, grazing, drought, and wildlife have all been developed for land owners/managers engaged in cattle or wildlife production systems in the South Texas Plains. The USDA, Natural Resource Conservation Service, has offered financial and technical assistance for land owners/managers in 17 Texas counties impacted by CFT since 2009. The program funds practices that control brush and improve fences, animal handling facilities, water distribution, and wildlife management ${ }^{2}$.

\section{Land-use and fractionation}

Landscape fragmentation resulting from changes in vegetation cover, property size, use of natural resources, and wildlife diversity and abundance is acknowledged to impact the ecology of

\footnotetext{
${ }^{2}$ http://www.tx.nrcs.usda.gov
}

tick-borne disease systems, including Lyme disease (Brownstein et al., 2005) and Crimean-Congo hemorrhagic fever (EstradaPeña et al., 2010). Two CFT outbreaks in 2009 provide a case study in contrasting land-use and fractionation and the impact of a growing human population. An outbreak involving $R$. annulatus occurred in the northern portion of the quarantine zone in country largely devoted to cattle production on large pastures (typically 500-2000 acres) where white-tailed deer (WTD) and human populations are relatively low. In contrast, an $R$. microplus outbreak in the southern portion was characterized by many landowners having small parcels of land (typically 50-200 acres), a comparatively high human population with widely variable land-use and a high concentration of WTD estimated to be one animal per four acres. The South Texas Plains ecoregion (approx. 20 million acres) is comprised of $67 \%$ native pasture (rangeland), $10 \%$ improved pasture, $4 \%$ wildlife management, $13 \%$ cropland (dryland/irrigated), and the remainder in a variety of uses (Gilliland et al., 2010). Crop and citrus enterprises are aggregated in the Rio Grande Valley at the very southern portion of the permanent quarantine zone, while the vast majority of land-use to the north is cattle and wildlife on rangeland and pasture. Rural land prices and sales in the South Texas Plains steadily increased from 1990 with sales peaking in 2004 and prices peaking in 2008, before economic recession brought about declines in both parameters (Gilliland et al., 2010). Over recent decades landowners-managers have integrated predominantly cow-calf operations with native and/or exotic game operations to diversify economic enterprises (Inglis, 1985). Increasing fragmentation of farms and ranches is resulting in rural property size decline driven by social and economic factors including profitability of agricultural enterprises, environmental concerns, and intergenerational land transfers. An evaluation of rural property patterns in Texas (Kjelland et al., 2007) found the strongest predictor of land fragmentation to be non-agricultural value. Changes in land-use and fragmentation are expected to continue to alter the ecology of CFT and the risks associated with bovine babesiosis. The operational impact of these changes on the CFTEP program is extended to the regulatory logistics and public relations associated with the elimination of outbreaks in smaller premises where livestock and wildlife ranching is now practiced. This requires a renewed effort to engage and raise awareness of program goals and procedures among diversified livestock producers.

\section{WILDLIFE AS ALTERNATIVE CATTLE FEVER TICK HOSTS White-tailed deer}

The deer Odocoileus virginianus, commonly known as WTD, was abundant and widespread prior to pioneer settlement (Young, 1956; Rue, 1978). Substantial WTD populations were a resource for meat and hides, and these became significant objects of trade and commerce. One central Texas trading house is reported to have baled and shipped 75,000 deer hides between 1844 and 1853 (Young, 1956). By the late 1800's WTD were at their lowest in many regions (Rue, 1978). The bovine-centered CFT eradication campaign made steady progress until the 1930's when deer infested with $R$. microplus were deemed responsible for persistent infestations in Florida (George, 1990). Though controversial, WTD population reductions were conducted in six counties after other 
tactics failed, and ticks were subsequently eliminated (George, 1990; Strom, 2009). It is noteworthy that R. annulatus was first described from specimens collected from WTD, then known as Cervus virginianus, in Florida (Say, 1821).

The esthetic and recreational hunting value of WTD remained, and conservationists working with state-federal agencies reestablished and conserved WTD populations throughout the U.S. In the Llano Basin of the Edwards Plateau ecoregion (Figure 1C), an area of approximately 525,000 acres, the average deer density in 1954 was 14.4 per 100 acres, 75,600 animals, and by 1961 deer density increased to 18.9 per 100 acres with a census of 99,750 animals (Rue, 1978). Successful WTD population growth in Texas through the 1960's was influenced by three factors: beneficial cover and browse was provided by brush vegetation communities; a more defined hunting season was established with conservation goals; and, elimination of the primary screwworm, Cochliomyia hominovorax (Rue, 1978). The Texas population in 2004 was estimated at 3.8 million animals (Pound et al., 2010). Range expansion for the Texas WTD subspecies included the Tamaulipan brushlands of Mexico where they are managed for overabundance today (Taylor, 1956; Martinez and Hewitt, 2001).

Most WTD responded to bi-weekly cattle gathering and dipping activities on a CFT infested ranch by temporarily moving to adjacent premises, then returning to the infested and quarantined pastures after activities subsided, while a small number moved into new home ranges (Hood and Inglis, 1974). The behavior of WTD on landscapes has primarily been investigated for deer management and conservation goals (Felix et al., 2007). Robust modeling and field studies are needed on the interactions of cattle and deer (and/or other wildlife species) behavior on tick-infested landscapes to define dynamic relationships of host diversity on tick dispersal and maintenance and to improve tactics for tick suppression and elimination as this aspect has been identified as a gap in our ability to develop effective control strategies to control parasites affecting livestock and wildlife (Morgan et al., 2004). The physiology and grooming behavior of WTD reduced both the number of $R$. annulatus successfully feeding and their subsequent fecundity (Cooksey et al., 1989). Nevertheless, the frequency of both CFT species infesting WTD in both Texas and Mexico increased (Gray et al., 1979; George, 1990). Movement of tick-infested WTD from Mexico across the Rio Grande is often the suspect, or confirmed source of infestations in Texas. Expanses of game fencing were erected as physical barriers to deer, and the previously successful bovine-centric eradication strategies were challenged. Infested premises where the pasture vacation option was implemented often resulted in prolonged infestations and quarantines suggesting WTD were capable of sustaining tick populations in the absence of cattle (George, 1990). Of the two CFT species, $R$. microplus is known to sustain populations on deer in the absence of cattle (Kistner and Hayes, 1970; George, 1990). Reliance on cattle dipping as a means of sponging ticks from infested land (Gray et al., 1979), and the implementation of WTD-specific treatment tactics have been integrated into the CFTEP (George et al., 2008; Pound et al., 2010). Efforts to eradicate CFT infesting alternative wildlife hosts such as WTD present a challenging situation for the CFTEP. The process of issuing quarantines and treating livestock and deer is a significant financial burden on federal and state agencies that also impacts livestock producers. Estimates indicated that the expense to systematically treat every cattle could average $\$ 250$ per head and lead to an $80 \%$ decline in net cash farm income (Anderson et al., 2010). During 2011, approximately 9\% of total CFTEP expenditures were allocated to CFT mitigation for deer. Future challenges include optimal integration of these tactics and other emerging technologies as discussed below in adaptable ways to different and changing landscape types for environmentally sound and sustained CFT eradication.

\section{Exotic ungulates}

Interests in foreign wildlife conservation, recreational hunting, and marketing exotic meats provided incentives for private landowners to import exotic ungulates and develop management programs. Initial importations date to the 1920's, and today Texas has more species and greater numbers of exotic game than any other state in North America (Mungall and Sheffield, 1994). Statewide surveys conducted by the Texas Parks and Wildlife Department in 1963 estimated 13 species established and 13,000 animals, and by the final survey in 1996 estimated 76 species and 190,000 animals. These surveys indicate approximately $2 / 3$ are confined by high game fencing and $1 / 3$ are free-ranging. The most successful introductions have been of hoof stock, most originating from Asia. The success of these animals in Texas is due in part to the similarity of respective foreign climates and lack of predators.

The South Texas Plains and Edwards Plateau ecoregions (Figure 1C) have the highest concentration of exotic animals adjacent to the international boundary and permanent quarantine zone (Mungall and Sheffield, 1994). Axis (Cervus axis), fallow (Cervus dama), and sika deer (Cervus nippon), nilgai (Boselaphus tragocamelus) and black buck antelope (Antilope cervicapra), mouflon (Ovis musimon), and aoudad sheep (Ammotragus lervia) comprise the most abundant species, and the range of several of these species are known to extend into Mexico. Exotic species discovered with infestations of either $R$. microplus or $R$. annulatus include nilgai, aoudad sheep, wapiti (Cervus canadensis), red deer (Cervus elaphus), fallow deer, and axis deer (Sheffield et al., 1983; Pound et al., 2010). Like R. microplus, the original home of nilgai is the Indian subcontinent. Wapiti and red deer were introduced in Mexico where free-ranging populations live along the border with south Texas (Gallina and Escobedo-Morales, 2009); there are anecdotal reports from Mexico of heavy R. microplus infestations in red deer. While the suitability of other exotic hoof stock as potential hosts for CTF is unknown, the adaptability of $R$. microplus to new wildlife hosts has been demonstrated in Brazil and New Caledonia (Cançado et al., 2009; De Meeûs et al., 2010).

Invasive feral swine (Sus scrofa) are found throughout the southern region and they have invaded the 10 ecoregions of Texas (Taylor et al., 1998; Rollins et al., 2007; Campbell and Long, 2009). The Texas feral swine population has recently been estimated to be at least 2 million animals (Campbell et al., 2008), and their success credited to high reproductive rate, omnivory, and adaptability (Mungall and Sheffield, 1994). They are significant pests in rural and urban environments, yet also considered valuable for recreational hunting (Rollins et al., 2007). Seven non-CFT species of Ixodid ticks have been found parasitizing feral swine in Texas ecoregions east and north of the border area (Sanders, 2011; 
Schuster, 2011). Six tick species are three-host ticks and one species, Dermacentor albipictus, is a one-host tick. The potential for feral swine to serve as a host for CFT is raised by the recovery of adult $R$. microplus from domestic pigs in Bangladesh (Islam et al., 2006; Ghosh et al., 2007). Additionally, feral swine create frequent breaches in game fences compromising barrier integrity to wildlife containment (Bodenchuk, 2010). Anthropogenic interests in native and exotic wildlife add host diversity for $R$. microplus and $R$. annulatus in this region, which provides new avenues for tick dispersal and maintenance. Future efforts to eliminate CFT in outbreaks involving exotic hosts will require integration of such factors as habitat use modification, home range management, nutrition, behavior, and the expertise of wildlife specialists to develop best practices (Figure 3).

\section{CLIMATE VARIABILITY AND CHANGE AS DRIVERS OF CFT OUTBREAK SURGES}

Solar cycles and global climate influence the dynamics of ecosystems at the macro level (Lean, 2010). A glance at global and national weather/climate events for 2011 provides context for the pathways of global change impacting CFTEP operations. Globally, 2011 was the second wettest year on record since 1900 and this was accompanied by the warmest annual above-average temperatures registered in the southern U.S. The drought in northern Mexico was ranked ninth in a list of top global climate/weather events and Texas experienced its driest year on record in 2011 (National Climatic Data Center, 2012).

Climatic factors limit the geographic distribution of tick species and consequently the epidemiology of tick-borne diseases is also susceptible to the influences of climate (Sonenshine and Mather, 1994; Gray et al., 2009). Where they are endemic, the abundance of tick species is influenced by changes in temperature and moisture. Climate variability is one of the drivers for the emergence and reemergence of tick-borne diseases (Lafferty, 2009; Randolph, 2010).

In addition to solar cycle activity, the interplay of oceanic and atmospheric processes results in cyclical phenomena that impact regional climates (Gurney and Sapiano, 2006). Examples of such phenomena include the El Niño/Southern Oscillation (ENSO), the Accumulated Cyclone Energy Index (ACE; Enfield and CidSerrano, 2010), and other oceanic indicators, which are linked to indices used to forecast weather conditions. Global environmental events influence the population ecology of arthropod-vectors and vector-borne diseases (Baylis and Githeko, 2006; Linthicum et al., 2008; Anyamba et al., 2012). Anomalies in these phenomena alter the ecological balance, which can result in outbreaks of pests and vector-borne diseases. A warning system based on temporal and spatial predictions of Rift Valley fever outbreak activity derived from analysis of ENSO-related climate anomalies measured through remote sensing of environmental parameters facilitated disease outbreak and mitigation activities (Anyamba et al., 2009). The ENSO, for example, was found to influence CFT populations in North America (Estrada-Peña et al., 2005). Areas in the southern U.S. are subject to sudden changes in habitat suitability for the CFT that are linked to ENSO. This trend highlights a risk for the CFTEP as divergent changes in climate can augment the threat of invasion by R. microplus or R. annulatus (Estrada-Peña and Venzal, 2006).
At the regional scale, it is noted that the number of tick events recorded within the permanent quarantine zone and in the free zone of south Texas covering fiscal years 1959 through 2011 shows distinct, recurring surges of CFT activity (Figure 5A). By averaging the first (1960-1980) and second (1990-2011) surges, a characteristic tick cycle was revealed (Figure 5B). Significantly, the rapid onset of the surge and equally rapid subsidence, or recovery,
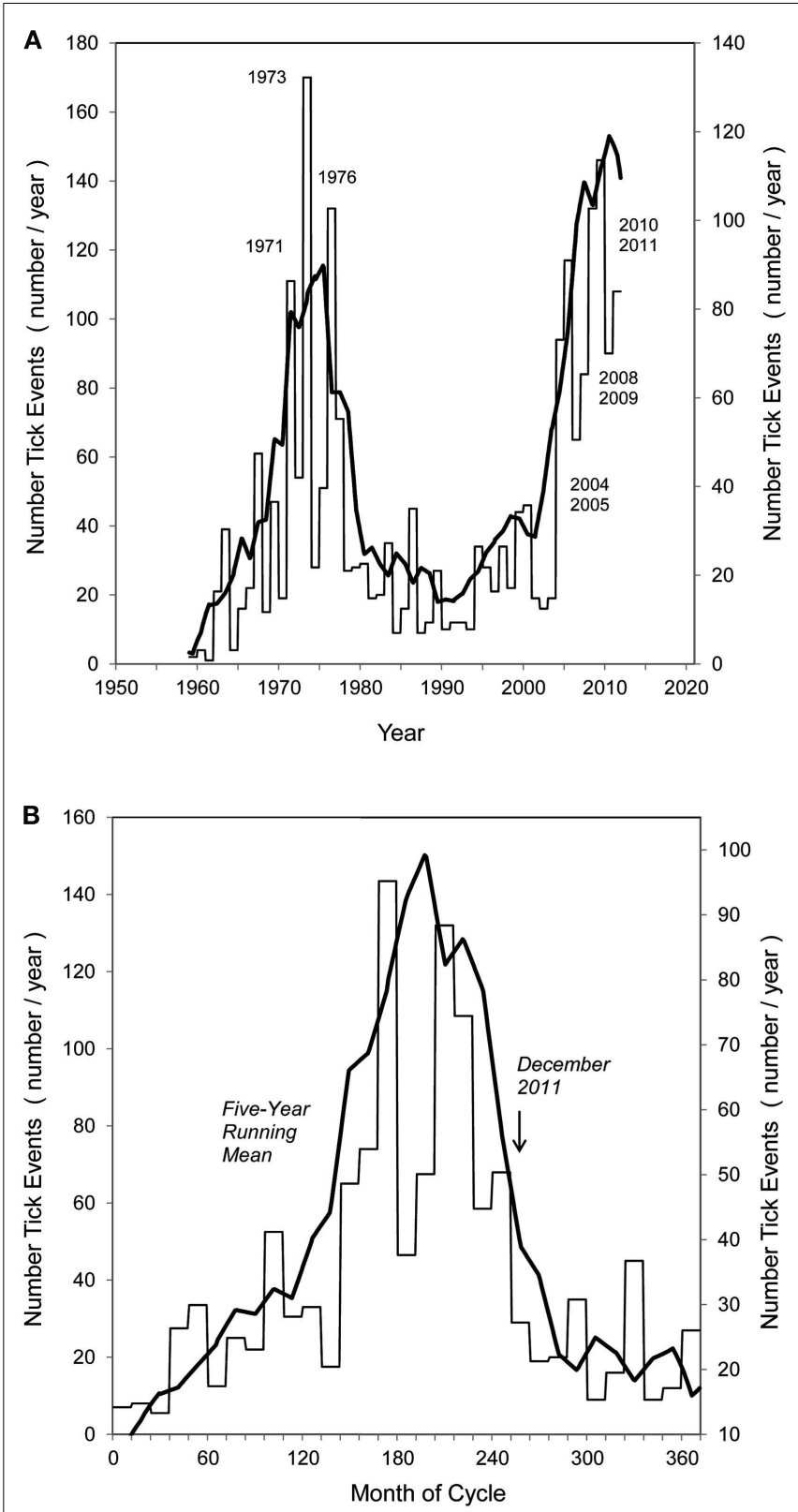

FIGURE 5 | (A,B) Pattern of tick surges in quarantine + free zones of south Texas, 1959-2011, with 5-year running mean (heavy line): (A) yearly level of tick events, showing major years of outbreak in 1970 and 2000 decades; (B) averaged surge periods of 1959-1989, and 1991-2011, showing sharp onset and subsidence of characteristic surge dynamic. December 2011 identifies last sample date and expected drop of tick levels over following year. 
suggests that this is a representative and recurring dynamic of CFT outbreaks in this region.

Fast Fourier Transform analysis was applied to test the hypothesis of recurring cycles of CFT outbreak activity (SeaSolve, 2004). In addition to identifying principal, recurring CFT events, Fast Fourier Transform analysis enables the recognition and quantification of embedded patterns, which can be important clues to other factors driving CFT population surges such as solar, oceanic, and/or precipitation cycles. Figures $\mathbf{6 A - C}$ show a dominant interval lasting 35 years for increased CFT activity in the permanent quarantine + free zone, 33 years in the permanent quarantine zone, and 36 years for outbreak activity in the free zone, respectively. In the latter, the pattern appears simple and likely the result of CFT infestations spreading beyond the permanent quarantine zone that includes a lag interval of about three years. It appears that other factors are operating in the permanent quarantine + free, and permanent quarantine zones (Figures 6A,B). Beyond annual variations, there seems to be a pattern that might include a 4-6 or 8.5 years cycle, which could repeat approximately every 17 years. This observation suggests the operation of ENSO effects with recurrences at those frequencies. It is hypothesized that the 33-36 year interval reflects the influence of the ACE operating at a multidecadal frequency. These spectral intervals are early approximations at this point, and it is recognized that the Fast Fourier Transform analysis is based on only two surges of CFT activity with the most recent surge apparently still in process.

A reconstruction of the wavelet analyses as shown in Figure 7 depicts how the results of the Fast Fourier Transform analysis can be applied to forecast future surges of CFT activity in the region. Should the pattern of 1959-2011 repeat itself, one could anticipate a third surge of tick activity in the 2040 decade; uncertainty on its timing and severity needs to be resolved through a better understanding of oceanic signals driving high rainfall intervals in the region, as explored below. Assessing future impacts of climate oscillations and climate perturbations, from tropical hurricanes to acute drought, by modeling normal and extreme conditions would better inform regulatory officials and policy makers on operational needs and regulatory changes as suggested for other disease systems influenced by global change (Garner et al., 2007; Woolhouse, 2011; Anyamba et al., 2012). In particular, strategic forecasting by the CFTEP would enable the adaptation of integrated protocols involving the use of different technologies to minimize the number of, and expedite the elimination of outbreaks. Examples of emerging technologies for integrated eradication are mentioned in the following section.

The field data show the first surge peaked in 1973 when 112 of 170 outbreaks were recorded in the free zone. It took 6 years to reduce the total number of outbreaks at a significant cost for producers and the CFTEP and TAHC, but CFT incursions into the free zone continued to be detected until 1990. The second surge perhaps peaked in 2009 and it appears to be subsiding now. Another a priori observation suggests that there is a lag interval where outbreaks in the permanent quarantine zone increase before a transient invasion of the free zone occurs. Thus, the historical record documents recurring, distinct periods of CFT outbreak activity in the south Texas-Mexico border region. The likelihood of recurring episodes is supported by statistical analysis and reconstruction of cycle frequencies in the CFT record. Climate warming was identified as a trend that can alter habitat suitability for R. microplus in the Americas including the southeastern U.S. (Estrada-Peña, 2001).

A shift in mean temperature at the global and century scale is primarily a phenomenon of changes at high latitudes of the northern and southern hemispheres. Mean temperature changes in specific regions such as south Texas may or may not coincide with this global trend. The regional trend, for example, decreased from 1895 through about 1975, but then warmed to levels tracking the global increase. Of note, the temperature increases since
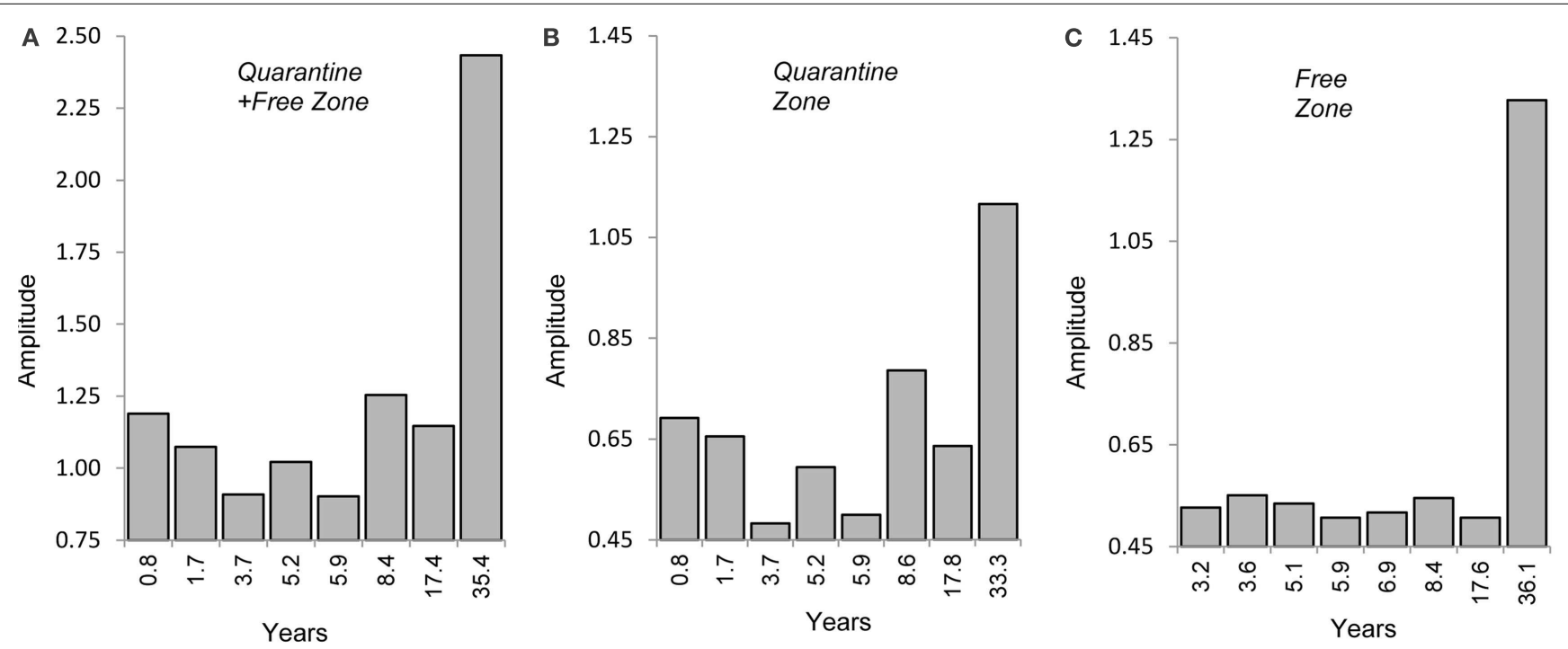

FIGURE 6 | (A-C) Fast Fourier Transform analysis showing strength (amplitude) of main and sub-frequencies (years) of tick outbreak patterns: (A) Quarantine + Free Zone; (B) quarantine zone; (C) Free zone. 


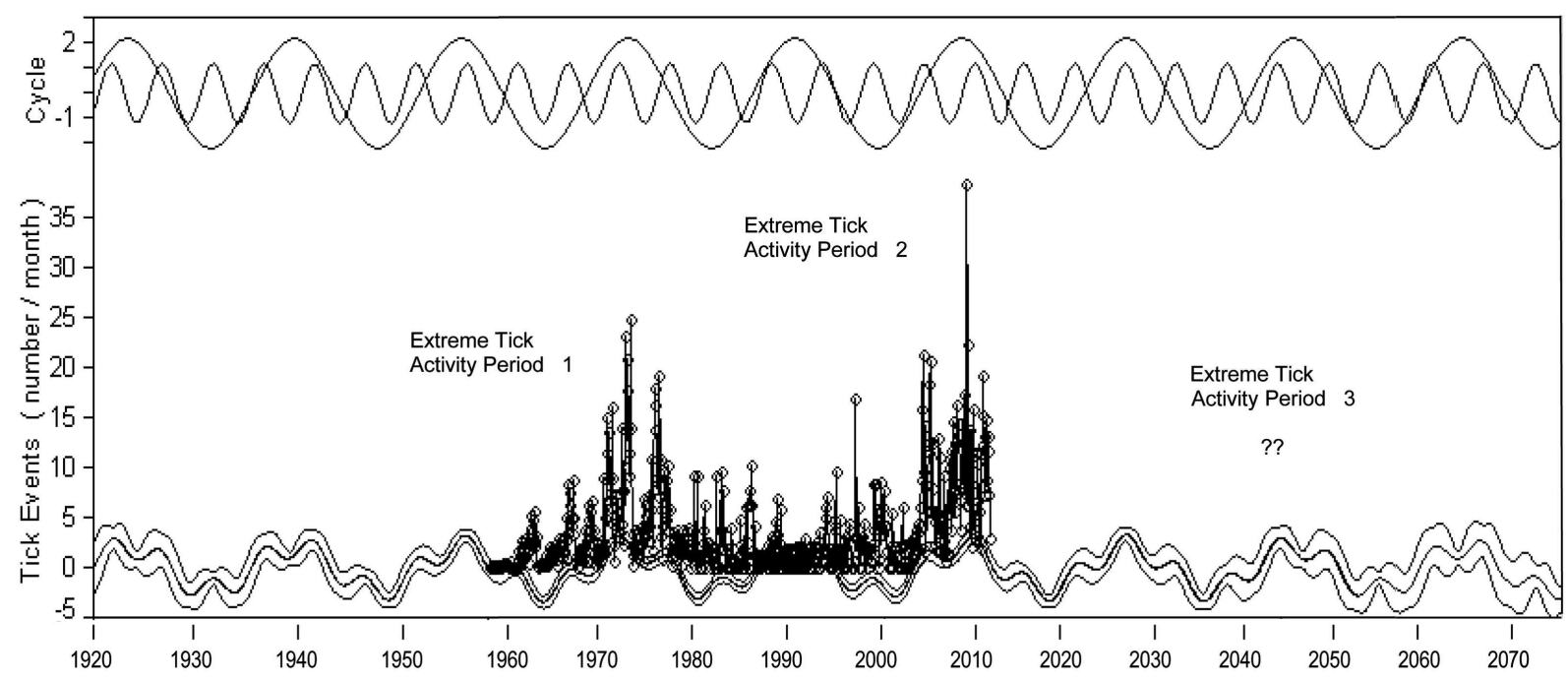

FIGURE 7 | Fast Fourier Transform wavelet analysis of tick events in Quarantine + Free Zone. Two main cycle frequencies are shown at top of graph. Tick outbreak data (1959-2011) on which analysis is based is shown in vertical line and point format. Tick cycles are backcast to 1920 and forecast to 2077 with $90 \%$ confidence limits. A period of increased CFT outbreak activity is posited to occur during the 2040 decade.
1975 occurred in all south Texas NOAA Climate regions from the coast (Region 10) inland to NOAA Climate Region 5, west of the Big Bend border area along the Rio Grande. Moreover, the high plains of the U.S. continental interior, i.e., Platte Drainage, CO, also showed this post-1975 warming pattern, as did Caribbean Region sea surface temperatures. Hence, it appears that a widespread regional temperature trend consistent with, and possibly driven in part by changing global conditions could be influencing CFT outbreak activity, especially in the case of the tropically adapted $R$. microplus as suggested by Estrada-Peña (2001).

Because relative humidity is an important determinant of tick survival (Estrada-Peña, 2001; Corson et al., 2004; Estrada-Peña and Venzal, 2006), we probed for a connection between outbreak surges and long-term regional rainfall. We also queried the possibility that ocean indicators such as the ACE not only drive the rainfall patterns in south Texas (Enfield et al., 2001), but offer an advanced signal of pending major precipitation shifts. The analysis of rainfall in the quarantine + free zones revealed two marked wet periods when the 10 -year running precipitation average was applied (Figure 8A). The 10-year averaging was required because any monthly pattern was masked by especially high variability and no apparent regression trend. Notably, these prolonged wet intervals coincide closely with the two CFT outbreak surges (Figure 8A). Moreover, the high rainfall interval appears driven by the ACE, which is a measure of North Atlantic and Caribbean Region hurricane severity that brings rain into south Florida and south Texas. Since 1975, the lag between the intervals of high rain periods in south Texas and increase in ACE is $~ 3-5$ years (Figure 8B). Hence, a simple climatic algorithm to track outbreak surges that offers the additional possibility of anticipating such surges years in advance is presented here. The Atlantic Multidecadal Oscillation, thought to correlate with and drive the ACE (Enfield and Cid-Serrano, 2010), also provides advance warning of changes in the south Texas rainfall.

\section{ACARICIDE RESISTANCE RISK AND TECHNOLOGICAL OPPORTUNITIES FOR INTEGRATED ERADICATION}

The CFT R. microplus is ranked as the sixth most pesticideresistant arthropod in the world (Whalon et al., 2008). This situation reflects the historical reliance on chemical acaricides, which are pesticides that kill ticks, to control and eradicate CFT. Arsenical dips were introduced in 1911 and they were used by the CFTEP until the 1960s (Graham and Hourrigan, 1977). Organophosphate acaricides replaced arsenical dips in 1967, and in 1971 the CFTEP started using coumaphos to dip cattle and spray horses. Additionally, an injectable macrocyclic lactone acaricide formulation is used on a need-basis by the CFTEP during outbreaks where dipping alone presents difficulties for eradication. The two technologies employed to eliminate CFT infesting WTD are ivermectin-medicated corn and topical permethrin self-treatment using a bait station fitted with the "2-poster" adapter (Pound et al., 2010). Corn medicated with ivermectin was used to eradicate long-term CFT infestations maintained by wapiti and WTD (Pound et al., 2009).

In Mexico, organophosphate acaricides were used for the national tick eradication program between 1974 and 1984 (Trapaga, 1989). Pyrethroids and amitraz were authorized for CFT control in Mexico since 1985 (Rosario-Cruz et al., 2009). The use of amitraz gained popularity after CFT became refractory to treatment with organophosphates and pyrethroids, but resistance to amitraz was eventually reported in 2001 (Domínguez-García et al., 2010). The ticks have also evolved resistance to fipronil and multiple resistance to organophosphates, pyrethroids, amitraz, and ivermectin in Mexico (Miller et al., 2008; Fernández-Salas et al., 2012). Resistance to organophosphates and pyrethroids has been detected in CFT collected in Texas (Miller et al., 2005, 2007). Surveillance of acaricide resistance in CFT from outbreaks and other sources is an ongoing effort by the Cattle Fever 

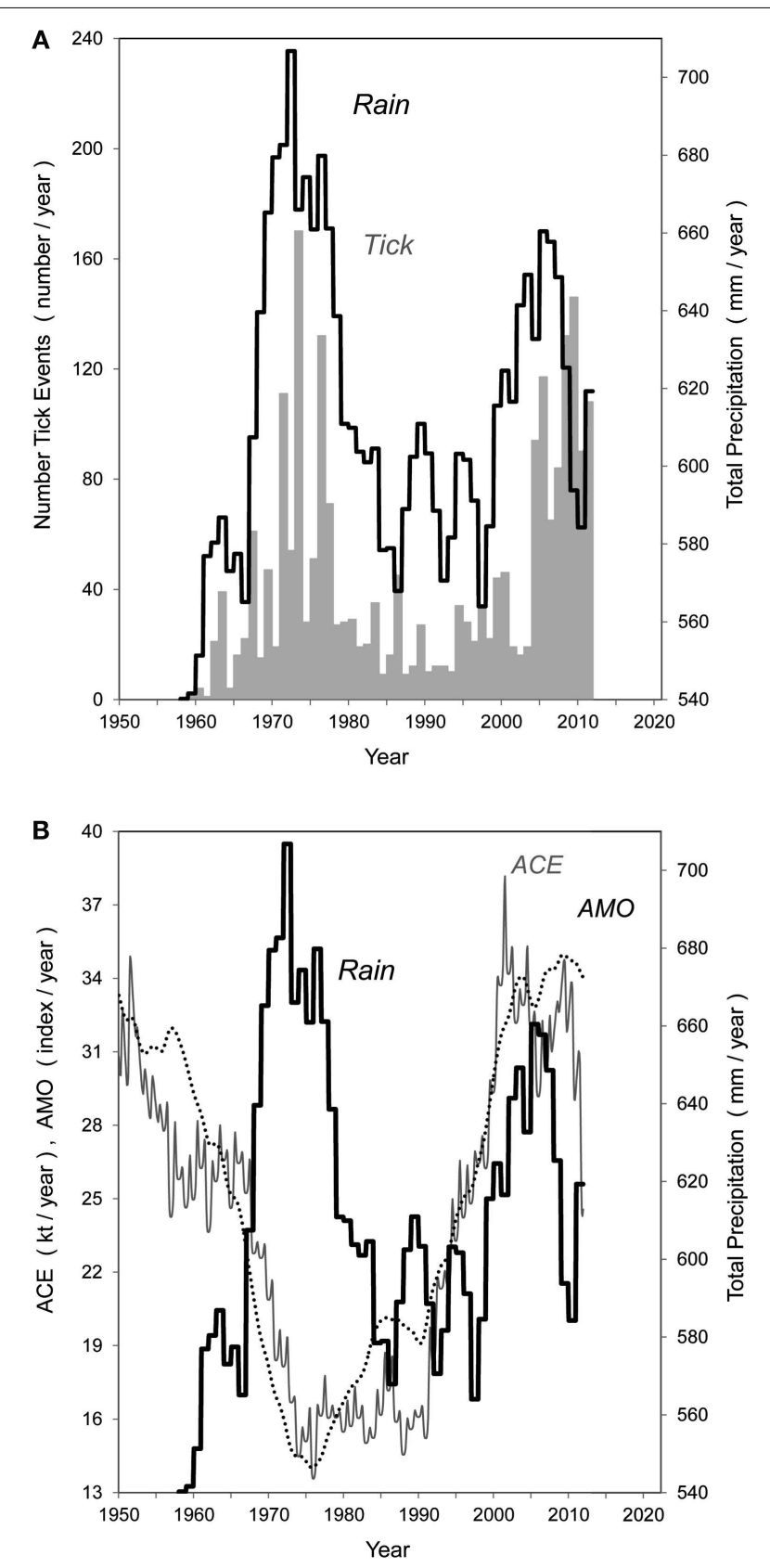

FIGURE 8 | (A,B) Comparison of annual total precipitation (rain, heavy line) in south Texas, 1959-2011 to: (A) number of tick events in quarantine + free zones (light gray); (B) magnitude of the annual Accumulated Cyclone Energy Index (ACE) and Atlantic Multidecadal Oscillation (AMO). The AMO at $1 /(45 x+25)$ of scale shown. No lags are applied.

Tick Research Laboratory of the USDA-Agricultural Research Service because this is a constant threat to CFTEP operations.

Anti-CFT vaccination in cattle and wildlife, and the passive administration of systemic acaricides for cattle are two technologies that could be used in an integrated fashion by the CFTEP
(Pérez de León et al., 2010). Vaccines against R. microplus based on the protective antigen $\mathrm{Bm} 86$ were developed and marketed under the names TickGARD (Willadsen et al., 1995), and Gavac (Canales et al., 1997). Their efficacy against that CFT species generally ranges from 10 to $89 \%$ (Willadsen, 2008). The level of efficacy reported for vaccines containing a recombinant form of Bm86 varies according to, among other things, the expression system used for vaccine production, characteristics of the tick population targeted, and host factors (de la Fuente et al., 1999; Patarroyo et al., 2002; Sitte et al., 2002; Casquero Cunha et al., 2012). It has been postulated that sequence variation in the $b m 86$ locus is associated with low susceptibility of certain $R$. microplus populations infesting cattle immunized with commercial Bm86-based vaccines (García-García et al., 1999). Interestingly, the efficacy of Bm86-based vaccines against $R$. annulatus is $>99 \%$; this level of efficacy is equivalent to that obtained with commercial acaricides in the absence of resistance. Anti-CFT vaccines based on Bm86 play an important role in integrated tick management systems (de la Fuente et al., 2007; Willadsen, 2008). Strategies combining anti-CFT vaccination and acaricides were shown to reduce the number of acaricidal applications necessary for tick control (de la Fuente et al., 2007), which also extends the useful life of acaricides by delaying the development of acaricide resistance. Gavac is not commercially available in the U.S. This vaccine was $99 \%$ efficacious against an outbreak strain of $R$. annulatus (Miller et al., 2012).

The post-genomic era offers the opportunity to take a systems biology-based approach to antigen discovery and vaccine development (Oberg et al., 2011). A web-based repository of $R$. microplus genomic data is helping with the identification and selection of sequences coding for molecules that can be tested as protective antigens (Bellgard et al., 2012). Ecologically based modeling can also be applied to evaluate and adjust various factors to maximize vaccine efficacy against CFT invading the U.S. (Miller et al., 2012). All these approaches are being applied to discover novel antigens that protect cattle in the permanent quarantine zone against $R$. microplus infestation, which could also be used to vaccinate WTD (Guerrero et al., 2012). Carreón et al. (2012) proved the feasibility of protecting WTD against CFT infestation through vaccination. The utility of vaccinating WTD for CFT eradication in south Texas could be tested initially in high-fenced premises. Combining vaccination with the existing CFT treatments for WTD will eliminate their role as reservoirs for the ticks.

As compared to other suitable hosts, populations of CFT realize their full reproductive potential when parasitizing cattle. Although it is likely that CFTEP strategies will remain focused on eliminating CFT infesting cattle, the use of methods applied to wildlife is needed because it appears that pasture vacation represents an anachronism from the time when cattle, horses, mules, and asses were the only hosts of concern (George et al., 2008). Therefore, it is proposed that the combined use of emerging technologies like vaccination of cattle and WTD against CFT and the use of an ivermectin-medicated feed block be explored. The integration of these tools with existing treatment protocols could lessen the economic and operational impacts of quarantines on producers. 


\section{RISK FOR WILDLIFE WITH STRAINS OF B. BOVIS AND B. BIGEMINA PATHOGENIC TO CATTLE}

Attempts to infect WTD with the agents of bovine babesiosis were unsuccessful (Kuttler et al., 1972). A study investigating the possibility that WTD might serve as a reservoir of bovine babesiosis revealed that the addition of bovine serum was required for in vitro culture of B. bovis in WTD erythrocytes (Holman et al., 1993). Serologic evidence and results from PCR tests indicated that WTD in Mexico could be infected with B. bovis and B. bigemina (Cantu-Covarrubias et al., 2009). Similar evidence exists for WTD in Texas (Holman et al., 2011). However, the data thus far suggests that WTD bitten by CFT infected with B. bovis or B. bigemina function as diluting hosts because these piroplasms are unable to undergo the asexual portion of their life cycle in WTD and become infective for CFT. The deer may be having a zooprophylactic effect by reducing the prevalence of infected CFT in the environment.

The nilgai is a tropically adapted bovid that poses a risk for the re-emergence of bovine babesiosis in the U.S. because, in addition to its host ability for CFT, this species adapts well to agricultural areas and commingles with cattle in south Texas (Sheffield et al., 1971; Davey, 1993; Leslie, 2008). Babesia infection in a nilgai from India was reported (Baviskar et al., 2009). There are approximately 30,000 nilgais along the south TexasMexico border and a population in Mexico was polymerase chain reaction-positive for $B$. bovis and B. bigemina (Cárdenas-Canales et al., 2011).

\section{PERSPECTIVES}

The predominant CFT species at the beginning of the eradication campaign was R. annulatus. By comparison R. microplus is a more invasive species. Records indicate CFT outbreaks in south Texas are frequently caused by $R$. microplus. The invasion and re-invasion of other parts of the world by $R$. microplus highlight the danger this tick poses to U.S. animal agriculture. Climate change could augment the economic impact of CFT by influencing habitat suitability and shifts in potential distribution of both species. Climate oscillations of wet and dry periods will undoubtedly continue to impact CFT and the preparedness of the CFTEP to respond to these changes. Additional hypothesis-driven research is required to effectively understand and manage the risk of CFT and bovine babesiosis re-emergence in the U.S. The complicated nature of current and future problems driven by global change requires that societal, environmental, scientific, and policy considerations be integrated to develop the most effective and sustainable strategies and goals to prevent re-establishment of CFT and/or outbreaks of bovine babesiosis (Figure 3).

\section{REFERENCES}

Agricultural Research Service. (1968). The Fight Against Cattle Fever Ticks. Hyattsville, MD: U.S. Government Printing Office, 320-594.

Aguilar, J. (2011). Cartel Violence Complicates Tick Eradication Plan. New York Times. Available at: http://www.nytimes.com/2011/04/ 17/us/17ttticks.html [accessed April $16,2011]$.
Anderson, D. P., Hagerman, A. D., Teel, P. D., Wagner, G. G., Outlaw, J. L., and Herbst, B. K. (2010). Economic Impact of Expanded Fever Tick Range. Research Report 10-2. College Station, TX: Agricultural and Food Policy Center, Texas AgriLife Research.

Anyamba, A., Chretien, J. P., Small, J., Tucker, C. J., Formenty, P. B., Richardson, J. H., Britch, S. C.,

Analyses of climate change effects presented here demonstrate that North Atlantic oceanic indicators, i.e., AMO and ACE, and region-scale rainfall shifts have a marked impact on periodic, CFT outbreak activity in south Texas, and may provide opportunity to develop responsive surveillance strategies. Here, it was documented that the collection and analysis of meaningful data allowing assessment and prediction to identify early warnings of pending changes in CFT outbreak activity is possible. It is recognized that future developments in monitoring and interpreting important ocean signals such as the AMO and ACE will continue to improve predictive power. Ongoing and future efforts to carefully systematize CFT records and put them into electronic format for pre-structured models designed to share with and fully inform decision makers at all levels is justified.

Comprehensive studies are advocated to explore thoroughly climate impacts on CFT, as well as other ticks, to design and integrate best management practices to evaluate ecosystem shifts affecting emergence of tick-borne diseases, and to inform policy makers for rational and effective decision making. This knowledge base could be used as the foundation to create and implement an international CFT monitoring and prediction program for the assessment and analysis of changes in tick distribution, ecology, host utilization, and disease epidemiology to mitigate the economic impact of these ticks and the pathogens they transmit. Such systems have been applied successfully to other arthropod-borne diseases and they could be consolidated in existing databases (Anyamba et al., 2009; Gale et al., 2010; Vesco et al., 2011). Worldwide coordination to adapt and refine prediction systems for ticks and tickborne diseases will enable the enhancement of public health and veterinary services programs to anticipate, prepare, and respond to these emerging and re-emerging human and animal health threats (Institute of Medicine, and National Research Council, 2009).

\section{ACKNOWLEDGMENTS}

Thanks to Sherri Brown and Helen Ramsey for outstanding editorial support and to Otto Strey for graphics support to create Figures 1A-C. Drs. Dan Strickman, John Goolsby, and Samuel Liu provided constructive comments on an earlier version of the manuscript. The research of Drs. Pérez de León, Felix Guerrero, and Robert Miller is supported by appropriated funds for projects 6205-32000-031-00D and 6205-32000-034$00 D$. Dr. Schuster's research is funded in part through NIFA project TEXR-2009-05759. USDA is an equal opportunity provider and employer. Ms. Johanna Reichen with the Frontiers Production Office is gratefully acknowledged for expert production coordination.

Schnabel, D. C., Erickson, R. L., and Linthicum, K. J. (2009). Prediction of a Rift Valley Fever outbreak. Proc. Natl. Acad. Sci. U.S.A. 106, 955-959.

Anyamba, A., Linthicum, K. J., Small, J. L., Collins, K. M., Tucker, C. J., Pak, E. W., Britch, S. C., Eastman, J. R., Pinzon, J. E., and Russell, K. L. (2012). Climate teleconnections and recent patterns of human and animal disease outbreaks.
PLoS Negl. Trop. Dis. 6, e1465. doi:10.1371/journal.pntd.00011465

Archer, S., Scifres, C. J., Bassham, C. R., and Maggio, R. (1988). Autogenic succession in a subtropical savanna: conversion of grassland to thorn woodland. Ecol. Monogr. 58, 111-127.

Aubry, P., and Geale, D. W. (2011). A review of bovine anaplasmosis. Transbound. Emerg. Dis. 58, 1-30. 
Barré, N., Bianchi, M., and Chardonnet, L. (2001). Role of Rusa deer Cervus timorensis russa in the cycle of the cattle tick Boophilus microplus in New Caledonia. Exp. Appl. Acarol. 25, 79-96.

Baviskar, B., Ingle, K., Gawande, P., Raut, S., Sirothia, K., and Bhandarkar, A. (2009). First report on occurrence of Babesia infection in nilgai Boselaphus tragocamelus from central India. J. Threat. Taxa 1, 196.

Baylis, M., and Githeko, A. K. (2006). Foresight. Infectious Diseases: Preparing for the Future. T7.3: The Effects of Climate Change on Infectious Diseases of Animals. London: Office of Science and Innovation.

Bellgard, M., Moolhuijzen, P. M., Guerrero, F. D., Schibeci, D., RodriguezValle, M., Peterson, D. G., Dowd, S. E., Barrero, R., Hunter, A., Miller, R. J., and Lew-Tabor, A. E. (2012). CattleTickBase: internet-based analysis tools and bioinformatics repository of available genomics resources for Rhipicephalus (Boophilus) microplus. Int. J. Parasitol. 42, 161-169.

Bishopp, F. C. (1913). The occurrence of the Australian Cattle Tick and the Brown Dog-tick in Key West, Florida (Acarina, Ixodoidea). Ent. News 24, 366-368.

Black, P., and Nunn, M. (2009). "Impact of climate change and environmental changes on emerging and reemerging animal disease and animal production." Paper Presented at the 77th General Session World Organization for Animal Health, International Committee, Paris.

Bodenchuk, M. J. (2010). USDAAPHIS-Wildlife Services Feral Hog Project Accomplishments, 2008-2010. San Antonio, TX: Texas Department of Agriculture.

Bram, R. A., George, J. E., Reichar, R. E., and Tabachnick, W. J. (2002). Threat of foreign arthropod-borne pathogens to livestock in the United States. J. Med. Entomol. 39, 405-416.

Brouqui, P. (2011). Arthropod-borne diseases associated with political and social disorder. Annu. Rev. Entomol. 56, 357-374.

Brownstein, J. S., Skelly, D. K., Holford, T. R., and Fish, D. (2005). Forest fragmentation predicts local scale heterogeneity of Lyme disease risk. Oecologia 146, 469-475.

Bryce, S. A., Omernik, J. M., and Larsen, D. P. (1999). Ecoregions a geographic framework to guide risk characterization and ecosystem management. Environ. Pract. 1, 141-155.

Bulloch, W. (1935). Theobald Smith. J. Pathol. Bacteriol. 40, 621-635.
Camill, P. (2010). Global change. Nat. Educ. Knowl. 2, 49.

Campbell, T. A., DeYoung, R. W., Wehland, E. M., Grassman, L. I., Long, D. B., and DelgadoAcevedo, J. (2008). Feral swine exposure to selected viral and bacterial pathogens in southern Texas. J. Swine Health Prod. 16, 312-315.

Campbell, T. A., and Long, D. B. (2009). Feral swine damage and damage management in forested ecosystems. For. Ecol. Manage. 257, 2319-2336.

Canales, M., Enriquez, A., Ramos, E., Cabrera, D., Dandie, H., Soto, A., Falcon, V., Rodriguez, M., and de la Fuente, J. (1997). Large-scale production in Pichia pastoris of the recombinant vaccine Gavac against cattle tick. Vaccine 15, 414-422.

Cançado, P. H. D., Zucco, C. A., Piranda, E. M., Faccini, J. L. H., and Mourão, G. M. (2009). Rhipicephalus (Boophilus) microplus (Acari: Ixodidae) as a parasite of pampas deer (Ozoctoceros bezoarticus) and cattle in Brazil's Central Pantanal. Rev. Bras. Parasitol. Vet. 18, 42-46.

Cannon, A. J. (2012). Köppen versus the computer: comparing KöppenGeiger and multivariate regression tree climate classifications in terms of climate homogeneity. Hydrol. Earth Syst. Sci. 16, 217-229.

Cantu-Covarrubias, A., Ortega-Santos, J. A., García-Vázquez, Z., Mosqueda, J., Henke, S. E., and George, J. E. (2009). Epizootiology of Babesia bovis and Babesia bigemina in freeranging white-tailed deer in northeastern Mexico. J. Parasitol. 95, 536-542.

Cárdenas-Canales, E. M., OrtegaSantos, J. A., Campbell, T. A., Garciá-Vázquez, Z., CantúCovarrubias, A., Figueroa-Millán, J. V., DeYoung, R. W., Hewitt, D. G., and Bryant, F. C. (2011). Nilgai antelope in northern Mexico as a possible carrier for cattle fever ticks and Babesia bovis and Babesia bigemina. J. Wildl. Dis. 47, 777-779.

Cardozo, H., Nari, A., Franchi, M., Lopez, A., and Donatti, N. (1984). Estudios sobre la ecologia del Boophilus microplus en tres areas enzooticas del Uruguay. Veterinaria 20, 4-10.

Carreón, D., Pérez de la Lastra, J. M., Almazán, C., Canales, M., RuizFons, F., Boadella, M., MorenoCid, J. A., Villar, M., Gortázar, C., Reglero, M., Villarreal, R., and de la Fuente, J. (2012). Vaccination with BM86, subolesin and akirin protective antigens for the control of tick infestations in white tailed deer and red deer. Vaccine 30, 273-279.

Casquero Cunha, R., Pérez de León, A. A., Leivas Leite, F. P., da Silva Pinto, L., Gonçalves dos Santos, A. Jr., and Andreotti, R. (2012). Bovine immunoprotection against Rhipicephalus microplus with recombinant Bm86-Campo Grande antigen. Rev. Bras. Parasitol. Vet. (in press).

Cooksey, L. M., Davey, R. B., Ahrens, E. H., and George, J. E. (1989). Suitability of white-tailed deer as hosts for cattle fever ticks (Acari: Ixodidae). J. Med. Entomol. 26, 155-158.

Cooley, R. A. (1946). The Genera Boophilus Rhipicephalus, and Haemaphysalis (Ixodidae) of the New World. Washington: National Institutes of Health Bulletin No. 187, $1-54$.

Correll, D. S., and Johnston, M. C. (1970). Manual of the Vascular Plants of Texas. Renner: Texas Research Foundation.

Corson, M. S., Teel, P. D., and Grant, W. E. (2004). Microclimate influence in a physiological model of cattlefever tick (Boophilus spp.) population dynamics. Ecol. Modell. 180, 487-514.

Cotton, E. C., and Voorhees, J. F. (1911). The Cattle Tick as Affected by Climate. Bulletin No. 94, Knoxville, TN: Tennessee Agricultural Experiment Station.

Cumming, G. S., and Van Vuuren, D. P. (2006). Will climate change affect ectoparasite species ranges? Global Ecol. Biogeogr. 15, 486-497.

Curtis, C., and Francis, M. (1892). The Cattle Tick: Biology, Preventive Measures. Bulletin No. 24. College Station, TX: Texas Agricultural Experiment Station.

Davey, R. B. (1993). Stagewise mortality, ovipositional biology, and egg viability of Boophilus annulatus (Acari: Ixodidae) on Boselaphus tragocamelus (Artiodactyla: Bovidae). J. Med. Entomol. 30, 997-1002.

Davey, R. B., Pound, J. M., and Cooksey, L. M. (1994). Comparative reproduction and nonparasitic development of Boophilus microplus and hybridized Boophilus ticks (Acari: Ixodidae) under natural field conditions in subtropical South Texas. Exp. Appl. Acarol. 18, 185-200.

Daynes, P., and Gutierrez, J. (1980). Variations saisonniees de l'activite parasitaire de la tique du betail Boophilus microplus (Acari: Ixodidae) en Nouvelle-Caledonie. Rev.
Elev. Med. Vet. Pays. Trop. 33, 305-310.

de la Fuente, J., Almazan, C., Canales, M., Perez de la Lastra, J. M., Kocan, K. M., and Willadsen, P. (2007). A ten-year review of commercial vaccine performance for control of tick infestations on cattle. Anim. Health Res. Rev. 8, 23-28.

de la Fuente, J., Rodriguez, M., Montero, C., Redondo, M., GarcíaGarcía, J. C., Méndez, L., Serrano, E., Valdés, M., Enríquez, A., Canales, M., Ramos, E., Boué, O., Machado, H., and Lleonart, R. (1999). Vaccination against ticks (Boophilus spp.): the experience with the Bm86based vaccine Gavac. Genet. Anal. 15, 143-148.

De Meeûs, T., Koffi, B. B., Barré, N., de Garine-Wichatitsky, M., and Chevillon, C. (2010). Swift sympatric adaptation of a species of cattle tick to a new deer host in New Caledonia. Infect. Genet. Evol. 10, 976-983.

Domínguez-García, D. I., Rosario-Cruz, R., Almazán García, C., Saltijeral Oaxaca, J. A., and de la Fuente, J. (2010). Boophilus microplus: biological and molecular aspects of acaricide resistance and their impacts on animal health. Trop. Subtrop. Agroecosyst. 12, 181-192.

Enfield, D. B., and Cid-Serrano, L. (2010). Secular and multidecadal warmings in the North Atlantic and their relationships with major hurricane activity. Int. J. Climatol. 30, 174-184.

Enfield, D. B., Mestas-Nunez, A. M., and Trimble, P. J. (2001). The Atlantic multidecadal oscillation and its relationship to rainfall and river flows in the continental U.S. Geophys. Res. Lett. 28, 2077-2080.

Estrada-Peña,A. (2001). Climate warming and changes in habitat suitability for Boophilus microplus (Acari: Ixodidae) in Central America. J. Parasitol. 87, 978-987.

Estrada-Peña, A., Acedo, S., Quílez, J., and Del Cacho, E. (2005). A retrospective study of climatic suitability for the tick Rhipicephalus (Boophilus) microplus in the Americas. Glob. Ecol. Biogeogr. 14, 565-573.

Estrada-Peña, A., Bouattour, A., Camicas, J. L., Guglielmone, A., Horak, I., Jongejan, F., Latif, A., Pegram, R., and Walker, A. R. (2006). The known distribution and ecological preferences of the tick subgenus Boophilus (Acari: Ixodidae) in Africa and Latin America. Exp. Appl. Acarol. 38, 219-235.

Estrada-Peña, A., Vatansever, Z., Gargili, A., and Ergönul, O. (2010). The 
trend towards habitat fragmentation is the key factor driving the spread of Crimean-Congo haemorrhagic fever. Epidemiol. Infect. 138, 1194-1203.

Estrada-Peña, A., and Venzal, J. M. (2006). High-resolution predictive mapping for Boophilus annulatus and B. microplus (Acari: Ixodidae) in Mexico and Southern Texas. Vet. Parasitol. 142, 350-358.

Estrada-Peña, A. (2008). Climate, niche, ticks, and models: what they are and how we should interpret them. Parasitol. Res. 103(Suppl. 1), S87-S95.

Felix, A. B., Walsh, D. P., Hughey, B. D., Campa, H., and Winterstein, S. R. (2007). Applying landscape-scale habitat-potential models to understand deer spatial structure and movement patterns. J. Wildl. Manage. 71, 804-810.

Fernández-Salas, A., Rodríguez-Vivas, R. I., and Alonso-Díaz, M. A. (2012). First report of a Rhipicephalus microplus tick population multi-resistant to acaricides and ivermectin in the Mexican tropics. Vet. Parasitol. 183, 338-342.

Food and Agriculture Organization of the United Nations (FAO). (2008). Climate Change, Energy and Food Climate-Related Transboundary Pests and Diseases. Rome: FAO.

Food and Agriculture Organization of the United Nations (FAO). (2011). World Livestock 2011 - Livestock in Food Security. Rome: FAO.

Francis, M. (1894). A Device for Dipping Cattle to Destroy Ticks. Bulletin No. 30. College Station, TX: Texas Agricultural Experiment Station.

Gale, P., Estrada-Peña, A., Martinez, M., Ulrich, R. G., Wilson, A., Capelli, G., Phipps, P., de la Torre, A., Muñoz, M. J., Dottori, M., Mioulet, V., and Fooks, A. R. (2010). The feasibility of developing a risk assessment for the impact of climate change on the emergence of Crimean-Congo haemorrhagic fever in livestock in Europe: a review. J. Appl. Microbiol. 108, 1859-1870.

Gallina, S., and Escobedo-Morales, L. A. (2009). Análisis sobre las Unidades de Manejo (UMAs) de ciervo rojo (Cervus elaphus Linnaeus, 1758) y wapiti (Cervus canadensis (Erxleben, 1777) en México: problemática para la conservación de los ungulados nativos. Trop. Conserv. Sci. 2, 251-265.

García-García, J. C., Gonzalez, I. L., González, D. M., Valdés, M., Méndez, L., Lamberti, J., D’Agostino, B., Citroni, D., Fragoso, H., Ortiz, M., Rodríguez, M., and de la Fuente, J.
(1999). Sequence variations in the Boophilus microplus Bm86 locus and implications for immunoprotection in cattle vaccinated with this antigen. Exp. Appl. Acarol. 23, 883-895.

Garner, M. G., Dubé, C., Stevenson, M. A., Sanson, R. L., Estrada, C., and Griffin, J. (2007). Evaluating alternative approaches to managing animal disease outbreaks - the role of modelling in policy formulation. Vet. Ital. 43, 285-298.

George, J. (2008). The effects of global change on the threat of exotic arthropods and arthropod-borne pathogens to livestock in the United States. Ann. N. Y. Acad. Sci. 1149, 249-254.

George, J. E. (1989). The Eradication of Ticks - Cattle Fever Tick Eradication Programme in the USA: History, Achievements, Problems and Implications for Other Countries. Rome: Food and Agriculture Organization of the United Nations, FAO, 1-7.

George, J. E. (1990). Wildlife as a constraint to the eradication of Boophilus spp. (Acari: Ixodidae). J. Agric. Entomol. 7, 119-125.

George, J. E., Pound, J. M., Kammlah, D., and Lohmeyer, K. H. (2008). "Presumptive evidence for the role of the white-tailed deer in the epidemiology of Rhipicephalus (Boophilus) annulatus and Rhipicephalus (Boophilus) microplus (Acari:Ixodidae)," in VI Seminario Internacional de Parasitologia Animal, Boca del Rio Veracruz: Instituto Nacional de Investigaciones Forestales, Agricolas y Pecuaries.

Ghosh, S., Bansal, G. C., Gupta, S. C., Ray, D., Khan, M. Q., Irshad, H., Shahiduzzaman, M., Seitzer, U., and Ahmed, J. S. (2007). Status of tick distribution in Bangladesh, India, and Pakistan. Parasitol. Res. 101, 207-216.

Gilliland, C. E., Gunadekar, A., Wiehe, K., and Whitmore, S. (2010). Characteristics of Texas Land Markets, A Regional Analysis. Technical Report 1937. College Station, TX: Real Estate Center, Texas A \& M University.

Goolsby, J. A., Kirk, A. A., Moran, P. J., Racelis, A. E., Adamczyk, J. J., Cortés, E., Marcos García, M. Á., Martinez Jimenez, M., Summy, K. R., Ciomperlik, M. A., and Sands, D. P. A. (2011). Establishment of the armored scale, Rhizaspidiotus donacis, a biological control agent of Arundo donax. Southwest. Entomol. 36, 373-374.

Graham, O. H., and Hourrigan, J. L. (1977). Eradication programs for the arthropod parasites of livestock. J. Med. Entomol. 13, 629-658.

Gray, J., Dautel, H., Estrada-Peña, A., Kahl, O., and Lindgren, E. (2009). Effects of climate change on ticks and tick-borne diseases in Europe. Interdiscip. Perspect. Infect. Dis. 2009, 12.

Gray, J. H., Payne, R. L., Schubert, G. O., and Garnett, W. H. (1979). Implication of white-tailed deer in the Boophilus annulatus tick eradication program. Proc. Annu. Meet. U. S. Anim. Health Assoc. 83, 506-515.

Graybill, H. W. (1911). Studies on the Biology of the Texas-Fever Tick. Bulletin No. 130. Washington: USDA, Bureau of Animal Industries.

Guerrero, F. D., Bendele, K. G., Davey, R. B., and George, J. E. (2007). Detection of Babesia bigemina infection in strains of Rhipicephalus (Boophilus) microplus collected from outbreaks in south Texas. Vet. Parasitol. 145 156-163.

Guerrero, F. D., Miller, R. J., and Pérez de León, A. A. (2012) Anti-cattle tick vaccines: many candidate antigens, but will a commercially viable product emerge? Int. J. Parasitol. 42, 421-427.

Gurney, R., and Sapiano, M. (2006). Foresight. Infectious Diseases: Preparing for the Future. S10: State-ofScience Review: Earth Observation. London: Office of Science and Innovation.

Hanson, C., Ranganathan, J., Iceland, C., and Finisdore, J. (2008). The Corporate Ecosystem Services Review: Guidelines for Identifying Business Risks and Opportunities Arising from Ecosystem Change. Washington: Meridian Institute, World Resources Institute, World Business Council for Sustainable Development.

Harrus, S., and Baneth, G. (2005). Drivers for the emergence and reemergence of vector-borne protozoal and bacterial diseases. Int. J. Parasitol. 35, 1309-1318.

Hoberg, E. P., Polley, L., Jenkins, E. J. and Kutz, S. J. (2008). Pathogens of domestic and free-ranging ungulates: global climate change in temperate to boreal latitudes across North America. Rev. Sci. Tech. 27, 511-528.

Holman, P. J., Carroll, J. E., Pugh, R., and Davis, D. S. (2011). Molecular detection of Babesia bovis and Babesia bigemina in white-tailed deer (Odocoileus virginianus) from Tom Green County in central Texas. Vet. Parasitol. 177, 298-304.

Holman, P. J., Waldrup, K. A., Droleskey, R. E., Corrier, D. E., and Wagner,
G. G. (1993). In vitro growth of Babesia bovis in white-tailed deer (Odocoileus virginianus) erythrocytes. J. Parasitol. 79, 233-237.

Hood, R. E., and Inglis, J. M. (1974). Behavioral responses of whitetailed deer to intensive ranching operations. J. Wildl. Manage. 38, 488-498.

Hoogstraal, H., and Aeschlimann, A. (1982). Tick-host specificity. Bull. Soc. Entomol. Suisse 55, 5-32.

Inglis, J. M. (1985). "Wildlife management and IBMS," in Integrated Brush Management Systems for South Texas: Development and Implementation. Publication No. 2M-6-85. College Station, TX: Texas Agricultural Experiment Station.

Institute of Medicine, and National Research Council. (2009). Sustaining Global Surveillance and Response to Emerging Zoonotic Diseases. Washington, DC: The National Academies Press.

Islam, M. K., Alim, M. A., Tsuji, N., and Mondal, M. M. H. (2006). An investigation into the distribution, hostpreference and population density of Ixodid ticks affecting domestic animals in Bangladesh. Trop. Anim. Health Prod. 38, 485-490.

Jones, K. E., Patel, N. G., Levy, M. A., Storeygard, A., Balk, D., Gittleman, J. L., and Daszak, P. (2008). Global trends in emerging infectious diseases. Nature 451, 990-993.

Kistner, T. P., and Hayes, F. A. (1970). White-tailed deer as hosts of cattle fever ticks. J. Wildl. Dis. 6, 437-440.

Kjelland, M. E., Kreuter, U. P., Clendenin, G. A., Wilkins, R. N., Wu, X. B., Afanador, E. G., and Grant, W. E. (2007). Factors related to spatial patterns of rural land fragmentation in Texas. Environ. Manage. 40, 231-244.

Kuttler, K. L., Graham, O. H., Johnson, S. R., and Trevino, J. L. (1972). Unsuccessful attempts to establish cattle Babesia infections in white-tailed deer. J. Wildl. Dis. 8, 63-66.

Lafferty, K. (2009). The ecology of climate change and infectious diseases. Ecology 90, 888-900.

Lean, J. L. (2010). Cycles and trends in solar irradiance and climate. Wiley Interdiscip. Rev. Clim. Change 1, 111-122.

Leslie, D. M. (2008). Boselaphus tragocamelus (Artiodactyla: Bovidae). Mamm. Species 813, 1-16.

Linthicum, K. J., Britch, S. C., Anyamba, A., Small, J., Tucker, C. J., Chretien, J., and Sithiprasasna, R. (2008). "Ecology of Disease: the intersection of 
human and animal health," in VectorBorne Diseases: Understanding the Environmental, Human health, and Ecological Connections. Washington, D.C.: The National Academies Press.

Logue, J. N. (1995). Beyond the Germ Theory - The Story of Dr. Cooper Curtice. College Station: Texas A\&M University Press.

Lohmeyer, K. H., Pound, J. M., May, M. A., Kammlah, D. M., and Davey, R. B. (2011). Distribution of Rhipicephalus (Boophilus) annulatus (Acari: Ixodidae) infestations detected in the United States along the Texas/Mexico border. J. Med. Entomol. 48, 770-774.

Malone, J. B. (1989). Texas fever, twoheaded calves and the Hatch Act 100 years and counting for veterinary parasitology in the United States. Vet. Parasitol. 33, 3-29.

Martinez, A., and Hewitt, D. (2001). Sobrepoblacion de venado cola blanca en el noreste de Mexico. Ciencia UANL 4, 177-181.

McBride, W. D., and Mathews, K. Jr. (2011). The Diverse Structure and Organization of U.S. Beef Cow-Calf Farms. EIB-73. Washington: U.S. Department of Agriculture, Economic Research Service.

McCulloch, R. N., and Lewis, I. J. (1968). Ecological studies of the cattle tick, Boophilus microplus, in the North Coast district of New South Wales. Aust. J. Agric. Res. 19, 689-710.

Miller, R. J., Almazan, G. C., Estrada, O. M., Davey, R. B., and George, J. E. (2008). "A survey for fipronil-andivermectin-resistant Rhipicephalus (Boophilus) microplus collected in northern Mexico and the options for the management of acaricideresistant ticks with pesticides," Paper Presented at VI Seminario Internacional de Parasitologia: Impacto de las enfermedades parasitarias sobre la ganaderia globalizad. INIFAPINFARVET AMPAVE-CNG-UV. Boca del Rio, Veracruz.

Miller, R. J., Davey, R. B., and George, J. E. (2005). First report of organophosphate-resistant Boophilus microplus (Acari: Ixodidae) within the United States. J. Med. Entomol. 42, 912-917.

Miller, R. J., Davey, R. B., and George, J. E. (2007). First report of permethrin-resistant Boophilus microplus (Acari: Ixodidae) collected within the United States. J. Med. Entomol. 44, 308-315.

Miller, R. J., Estrada-Peña, A., Almazán, C., Allen, A., Jory, L., Yeater, K., Messenger, M., Ellis, D., and Pérez de León, A. A. (2012). Exploring the use of an anti-tick vaccine as a tool for the integrated eradication of the cattle fever tick, Rhipicephalus (Boophilus) annulatus. Vaccine, accepted.

Morgan, E. R., Milner-Gulland, E. J., Torgerson, P. R., and Medley, G. F. (2004). Ruminating on complexity: macroparasites of wildlife and livestock. Trends Ecol. Evol. 19, 181-188.

Mount, G. A., Haile, D. G., Davey, R. B., and Cooksey, L. M. (1991). Computer simulation of Boophilus cattle tick (Acari: Ixodidae) population dynamics. J. Med. Entomol. 28, 223-240.

Munderloh, U. G., and Kurtti, T. J. (2011). "Emerging and re-emerging tick-borne diseases: new challenges at the interface of human and animal health," in National Academy of Sciences, Washington, D.C., Critical needs and gaps in understanding prevention, amelioration, and resolution of Lyme and other tick-borne diseases: the short-term and long-term outcomes, A142-A166.

Mungall, E. C., and Sheffield, W. J. (1994). Exotics on the Range. College Station: Texas A\&M University Press.

Munroe, F., and Willis, N. (2007). The role of anticipation in enhancing prevention and preparedness. Vet. Ital. 43, 207-214.

Munroe, F. A. (2007). Integrated agricultural intelligence - a proposed framework. Vet. Ital. 43, 215-223.

National Climatic Data Center. (2012). 2011 National Highlights. Asheville, NC.

National Research Council of the National Academies. (2010). Toward Sustainable Agricultural Systems in the 21st Century. Washington, D.C.: The National Academies Press.

Newell, W., and Daugherty, M. S. (1906). The Cattle Tick (Boophilus annulatus): Studies of the Egg and Seed Tick Stages, a Simple Method of Eradicating the Tick. Circular No. 10. Baton Rouge, LA: State Crop Pest Commission of Louisiana.

Oberg, A. L., Kennedy, R. B., Li, P., Ovsyannikova, I. G., and Poland, G. A. (2011). Systems biology approaches to new vaccine development. Curr. Opin. Immunol. $23,436-443$.

Olson, S. H., and Patz, J. A. (2011). "Global environmental change and tick-borne disease incidence," in National Academy of Sciences, Washington, D.C., Critical needs and gaps in understanding prevention, amelioration, and resolution of Lyme and other tick-borne diseases: the short-term andlong-termoutcomes, A44-A66.
Palmer, W. A., Treverrow, N. L., and O'Neill, G. H. (1976). Factors affecting the detection of infestations of Boophilus microplus in tick control programs. Aust. Vet. J. 52, 321-324.

Patarroyo, J. H., Portela, R. W., De Castro, R. O., Pimentel, J. C., Guzman, F., Patarroyo, M. E, Vargas, M. I., Prates, A. A., and Mendes, M. A. (2002). Immunization of cattle with synthetic peptides derived from the Boophilus microplus gut protein (Bm86). Vet. Immunol. Immunopathol. 88, 163-172.

Peel, M. C., Finlayson, B. L., and McMahon, T. A. (2007). Updated world map of the Koppen-Geiger climate classification. Hydrol. Earth Syst. Sci. 11, 1633-1644.

Pegram, R. G., Wilson, D. D., and Hansen, J. W. (2000). Past and present national tick control programs. Why they succeed or fail. Ann. N. Y. Acad. Sci. 916, 546-554.

Pérez de León, A. A., Strickman, D. A., Knowles, D. P., Fish, D., Thacker, E. L., De La Fuente, J., Krause, P. J., Wikel, S. K., Miller, R., Wagner, G. G. Almazan, C., Hillman, R., Messenger, M. T., Ugstad, P. O., Duhaime, R. A., Teel, P. D., Ortega-Santos, A., Hewitt, D. G., Bowers, E. J., Bent, S. J., Cochran, M. H., McElwain, T. F., Scoles, G. A., Suarez, C. E., Davey, R. B., Freeman, J. M., Lohmeyer, K. H., Li, A. Y., Guerrero, F., Kammlah, D. M., Phillips, P. L., and Pound, J. M. (2010). One Health approach to identify research needs in bovine and human babesioses: workshop report. Parasit Vectors 3, 36-46.

Perry, B., Grace, D., and Sones, K. (2011). Current drivers and future directions of global livestock disease dynamics. Proc. Natl. Acad. Sci. U.S.A. doi: 10.1073/pnas.1012953108. [Epub ahead of print].

Pound, J. M., George, J. E., Kammlah, D. M., Lohmeyer, K. H., and Davey, R. B. (2010). Evidence for the role of white-tailed deer (Artiodactyla:Cervidae) in the epidemiology of cattle ticks and southern cattle ticks (Acari:Ixodidae) in reinfestations along the Texas/Mexico border in South Texas - A review and update. J. Econ. Entomol. 103, 211-218.

Pound, J. M., Miller, J. A., George, J. E., and Fish, D. (2009). The United States Department of Agriculture Northeast Area-wide Tick Control Project: history and protocol. Vector Borne Zoonotic Dis. 9, 365-370.

Pretty, J., Sutherland, W., Ashby, J., Auburn, J., Baulcombe, D., Bell, M., Bentley, J., Bickersteth, S., Brown, K.,
Burke, J., Campbell, H., Chen, K., Crowley, E., Crute, I., Dobbelaere, D., Edwards-Jones, G., Funes-Monzote, F., Godfray, C. J., Griffon, M., Gypmantisiri, P., Haddad, L., Halavatau, S., Herren, H., Holderness, M., Izac, A., Jones, M., Koohafkan, P., Lal, R., Lang, T., McNeely, J., Mueller, A., Nisbett, N., Noble, A., Pingali, P., Pinto, Y., Rabbinge, R., Ravindranath, N., Rola, A., Roling, N., Sage, C., Settle, W., Sha, J., Shiming, L., Simons, T., Smith, P., Strzepeck, K., Swaine, H., Terry, E., Tomich, T., Toulmin, C., Trigo, E., Twomlow, S., Vis, J., Wilson, J., and Pilgrim, S. (2010). The top 100 questions of importance to the future of global agriculture. Int. J. Agric. Sustain. 8, 219-236.

Racelis, A. E., Davey, R. B., Goolsby, J. A., Pérez de León, A. A., Varner, K., and Duhaime, R. (2012). Facilitative ecological interactions between invasive species: Arundo donax stands as favorable habitat for cattle ticks (Acari: Ixodidae) along the U.S.Mexico border. J. Med. Entomol. 49, 410-417.

Randolph, S. E. (2010). To what extent has climate change contributed to the recent epidemiology of tickborne diseases? Vet. Parasitol. 167, 92-94.

Rawlins, S. C. (1979). Seasonal variation in the population density of larvae of Boophilus microplus (Canestrini) (Acari: Ixodidae) in Jamaican pastures. Bull. Entomol. Res. 69, 87-91.

Reisen, W. (2010). Landscape epidemiology of vector-borne diseases. Annu. Rev. Entomol. 55, 461-483.

Rollins, D., Higginbotham, B. J., Cearley, K. A., and Wilkins, R. N. (2007). Appreciating feral hogs: extension education for diverse stakeholders in Texas. Hum. Wildl. Confl. 1, 192-198.

Rosario-Cruz, R., Almazán-García, C., Miller, R. J., Domínguez-García, D. I., Hernandez-Ortiz, R., and de la Fuente, J. (2009). Genetic basis and impact of tick acaricides resistance. Front. Biosci. 14, 2657-2665.

Rubel, F., and Kottek, M. (2010). Observed and projected climate shifts 1901-2100 depicted by world maps of the Köppen-Geiger climate classification. Meteorol. Z. 19, 135-141.

Rue, L. L. (1978). The Deer of North America. New York: Crown Publishers, Inc.

Sanders, D. (2011). Ticks and TickBorne Pathogens Associated with Feral Swine in Edwards Plateau and Gulf Prairies and Marshes Ecoregions of Texas. Ph.D. dissertation, Texas A\&M University, College Station. 
Say, T. (1821). An account of the Arachnides of the United States. J. Acad. Nat. Sci. Phila. 2, 59-82.

Schultz, M. (2008). Theobald Smith. Emerging Infect. Dis. 14, 1940-1942.

Schuster, A. (2011). Spatial and Temporal Survey of Feral Pig Ectoparasites in Three Texas Wildlife Districts. Doctoral dissertation, Texas A\&M University.

Scifres, C. J. (1980). Brush Management: Principles and Practices for Texas and the Southwest. College Station: Texas A\&M University Press.

Scifres, C. J. (1985). "IBMS: Ecological Basis and Evolution of Concepts," in Integrated Brush Management Systems for South Texas: Development and Implementation. Publication No. 2M-6-85. College Station, TX: Texas Agricultural Experiment Station.

Scifres, C. J., and Hamilton, W. T. (1985). "Selecting IBMS Components," in Integrated Brush Management Systems for South Texas: Development and Implementation. Publication No. 2M-6-85. College Station, TX: Texas Agricultural Experiment Station.

SeaSolve. (2004). AutoSignal: Pioneering Automated Signal Analysis and Advanced Filtering. Users Manual. Framingham, MA: SeaSolve Software Inc.

Sheffield, W. J., Ables, E. D., and Fall, B. A. (1971). Geographic and ecologic distribution of nilgai antelope in Texas. J. Wildl. 35, 250-257.

Sheffield, W. J., Fall, B. A., and Bennet, A. B. (1983). The Nilgai Antelope in Texas. Kleberg Studies in Natural Resources. Publication No. 2M10-83. College Station, TX: Texas Agricultural Experiment Station.

Simmons, J. (2011). The Three Rights: Food, Choice, Sustainability - Technology's Role in the 21st Century: Making Safe, Affordable and Abundant Food a Global Reality. Greenfield, IN: Elanco Animal Health.

Sitte, K., Brinkworth, R., East, I. J., and Jazwinska, E, C. (2002). A single amino acid deletion in the antigen binding site of BoLA-DRB3 is predicted to affect peptide binding. Vet. Immunol. Immunopathol. 85, 129-135.

Smith, J. E. (2007). Science and technology foresight: a provocative tool for contending with future challenges in food safety and public veterinary medicine. Vet. Ital. 43, 237-246.

Smith, T., and Kilbourne, F. L. (1893). United States Department of Agriculture Bureau of Animal Industries Bulletin, Washington: Government Printing Office.

Sonenshine, D. E., and Mather, T. N. (1994). Ecological Dynamics of TickBorne Zoonoses. New York: Oxford University Press.

Strom, C. (2009). Making Catfish Bait out of Government Boys: The Fight against Cattle Ticks and the Transformation of the Yeoman South. (Environmental History and the American South). Athens: University of Georgia Press.

Suk, J. E., Lyall, C., and Tait, J. (2008). Mapping the future dynamics of disease transmission: risk analysis in the United Kingdom Foresight programme on the detection and identification of infectious diseases. Euro Surveill. 13,1-7.

Sutherst, R. (2001). The vulnerability of animal and human health to parasites under global change. Int. J. Parasitol. 31, 933-948.

Tabachnick, W. (2010). Challenges in predicting climate and environmental effects on vector-borne disease episystems in a changing world. $J$. Exp. Biol. 213, 946-954.

Taylor, R. B., Hellgren, E. C., Gabor, T. M., and Ilse, L. M. (1998). Reproduction of feral pigs in southern Texas. J. Mammal. 9, 1325-1331.

Taylor, W. P. (1956). The Deer of North America. Washington, D.C.: The Stackpole Company and The Wildlife Management Institute.

Teel, P. D. (1991). Application of modeling to the ecology of Boophilus annulatus (Say) (Acari: Ixodidae). J. Agric. Entomol. 8, 291-296.

Teel, P. D., Corson, M. S., Grant, W. E., and Longnecker, M. T. (2003). Simulating biophysical and human factors that affect detection probability of cattle fever ticks (Boophilus spp.) in semi-arid thornshrublands of South Texas. Ecol. Modell. 170, 29-43.

Teel, P. D., Marin, S. L., Grant, W. E., and Stuth, J. W. (1997). Simulation of host-parasite-landscape interactions: influence of season and habitat on cattle fever tick (Boophilus sp.) population dynamics in rotational grazing systems. Ecol. Modell. 97, 87-97.

Teel, P. D., Strey, O. F., and Hurley, J. A. (2011). The TickApp for Texas and the Southern Region: a mobile smart Phone application. Available at: http://tickapp.tamu.edu

Trapaga, J. T. (1989). The Eradication of Ticks - La Campana Contra la Garrapata Boophilus spp en Mexico-Logros, Problemas y Perspectivas. Rome: Food and Agriculture Organization of the United Nations, FAO, 114-121.

Vannier, E., Gewurtz, B., and Krause, P. J. (2008). Human babesiosis. Infect. Dis. Clin. North Am. 22, 469-488.

Vesco, U., Knap, N., Labruna, M. B., Avšič-Županc, T., Estrada-Peña, A., Guglielmone, A. A., Bechara, G. H., Gueye, A., Lakos, A., Grindatto, A., Conte, V., and De Meneghi, D. (2011). An integrated database on ticks and tick-borne zoonoses in the tropics and subtropics with special reference to developing and emerging countries. Exp. Appl. Acarol. 54, 65-83.

Walker, A. R. (2011). Eradication and control of livestock ticks: biological, economic and social perspectives. Parasitology 138, 945-959.

Walker, A. R., Bouattour, A., Camicas, J. L., Estrada Pena, A., Horak, I. G., Latif, A. A., Pegram, R. G., and Preston, P. M. (2003). Ticks of Domestic Animals in Africa; A Guide to Identification of Species. Edinburgh: Bioscience Reports.

Welburn, S. (2011). One health: the 21 st century challenge. Vet. Rec. 168 , 614-615.

Whalon, M. E., Mota-Sanchez, D., and Hollingsworth, R. M. (2008). Global Pesticide Resistance in
Arthropods. Cambridge: CAB International.

Willadsen, P. (2008). "Anti-tick vaccines," in Ticks: Biology, Disease and Control, eds A. S. Bowman and P. A. Nuttall (Cambridge: Cambridge University Press), 424-446.

Willadsen, P., Bird, P., Cobon, G. S., and Hungerford, J. (1995). Commercialisation of a recombinant vaccine against Boophilus microplus. Parasitology 110, S43-S50.

Willis, N. G. (2007). The animal health foresight project. Vet. Ital. 43, 247-256.

Woolhouse, M. (2011). How to make predictions about future infectious disease risks. Philos. Trans. R. Soc. Lond. B Biol. Sci. 366, 2045-2054.

Young, S. P. (1956). "The deer, the Indians, and the American pioneers," in The Deer of North America, ed. W. P. Taylor (Harrisburg, PA: The Stackpole Company), 1-28.

Conflict of Interest Statement: The authors declare that the research was conducted in the absence of any commercial or financial relationships that could be construed as a potential conflict of interest.

Received: 14 February 2012; accepted: 22 May 2012; published online: 14 June 2012.

Citation: Pérez de León AA, Teel PD, Auclair AN, Messenger MT, Guerrero FD, Schuster $G$ and Miller RJ (2012) Integrated strategy for sustainable cattle fever tick eradication in USA is required to mitigate the impact of global change. Front. Physio. 3:195. doi: 10.3389/fphys.2012.00195

This article was submitted to Frontiers in Systems Biology, a specialty of Frontiers in Physiology.

Copyright (c) 2012 Pérez de León, Teel, Auclair, Messenger, Guerrero, Schuster and Miller. This is an open-access article distributed under the terms of the Creative Commons Attribution Non Commercial License, which permits noncommercial use, distribution, and reproduction in other forums, provided the original authors and source are credited. 